\title{
Remote Sensing of Grassland Production and Management-A Review
}

\author{
Sophie Reinermann ${ }^{1, *}$, Sarah Asam ${ }^{2}\left(\mathbb{C}\right.$ and Claudia Kuenzer ${ }^{1,2}$ \\ 1 Department of Remote Sensing, Institute of Geography and Geology, University of Wuerzburg, \\ 97074 Wuerzburg, Germany; claudia.kuenzer@dlr.de \\ 2 German Remote Sensing Data Center (DFD), Earth Observation Center (EOC), German Aerospace \\ Center (DLR), 82234 Wessling, Germany; sarah.asam@dlr.de \\ * Correspondence: sophie.reinermann@dlr.de
}

Received: 18 April 2020; Accepted: 15 June 2020; Published: 17 June 2020

\begin{abstract}
Grasslands cover one third of the earth's terrestrial surface and are mainly used for livestock production. The usage type, use intensity and condition of grasslands are often unclear. Remote sensing enables the analysis of grassland production and management on large spatial scales and with high temporal resolution. Despite growing numbers of studies in the field, remote sensing applications in grassland biomes are underrepresented in literature and less streamlined compared to other vegetation types. By reviewing articles within research on satellite-based remote sensing of grassland production traits and management, we describe and evaluate methods and results and reveal spatial and temporal patterns of existing work. In addition, we highlight research gaps and suggest research opportunities. The focus is on managed grasslands and pastures and special emphasize is given to the assessment of studies on grazing intensity and mowing detection based on earth observation data. Grazing and mowing highly influence the production and ecology of grassland and are major grassland management types. In total, 253 research articles were reviewed. The majority of these studies focused on grassland production traits and only 80 articles were about grassland management and use intensity. While the remote sensing-based analysis of grassland production heavily relied on empirical relationships between ground-truth and satellite data or radiation transfer models, the used methods to detect and investigate grassland management differed. In addition, this review identified that studies on grassland production traits with satellite data often lacked including spatial management information into the analyses. Studies focusing on grassland management and use intensity mostly investigated rather small study areas with homogeneous intensity levels among the grassland parcels. Combining grassland production estimations with management information, while accounting for the variability among grasslands, is recommended to facilitate the development of large-scale continuous monitoring and remote sensing grassland products, which have been rare thus far.
\end{abstract}

Keywords: pasture; use intensity; grazing; mowing; productivity; biomass; yield; satellite data; optical; SAR

\section{Introduction}

\subsection{The Role and Importance of Grasslands Worldwide}

Grasslands cover about one third of the earth's terrestrial surface $[1,2]$ and they occur on every continent apart from Antarctica [3]. In total, 70\% of the global agricultural area consists of grasslands [1]. Their usage for livestock production and accompanying products such as milk, wool and leather serve as a basis of existence for many people [3]. For almost a billion people worldwide, livestock directly 
contributes to the livelihoods and food security [4]. In developing countries and low-income households, livestock production is particularly important. In the Sahel, pastoral systems account for $30 \%$ to around $80 \%$ of national GDPs [5]. For multiple countries in South America, Africa and Asia, livestock was estimated to constitute on average $12.3 \%$ of the total household income [6].

Apart from providing forage for livestock production, grasslands fulfill several functions and ecosystem services, which make them essential. The most important ones are carbon storage, biodiversity, water purification, erosion control and recreation [2,3,7]. In the light of global climate change, carbon sequestration and storage play increasing roles. Globally, grasslands store about $50 \%$ more carbon than forests due to the large area they cover [8]. In future climates, the role of grasslands as carbon sinks might further increase in some regions, as grasslands are assumed to be more resilient towards higher temperatures than forests, for example [9]. Within grassland ecosystems, carbon is mostly stored below ground and building a stable pool takes several years [10]. Therefore, the age of the grassland has an influence on the carbon storage. When grasslands are turned to croplands, carbon is released [11]. Extreme climate conditions, in particular droughts, can harm grasslands severely and reduce their productivity [12]. In terms of biodiversity, less intensively used grasslands (i.e., with low mowing frequency) can be high in plant species richness and endemism rate, especially compared to agriculturally used sites [13]. In addition, they provide valuable habitats for many bird species and insects [13-15].

\subsection{The Definition of Grasslands}

Grasslands worldwide are relatively heterogeneous, which makes a general definition difficult (see a compilation of definitions in [3]). In contrast to forests, grasslands cannot be easily described by the occurrence or absence of tree species. Grasslands do not only consist of grass species (Poaceae), but also contain other herbaceous vegetation, such as herbs, shrubs and trees to a certain degree [2,16]. They are the "in-between" class [16] and are often defined by the absence of other features [3]. In particular, it was proposed that for grasslands the bush cover should not exceed $25 \%$ and the tree cover has to be smaller than $10 \%$ in temperate and $40 \%$ in tropical regions, respectively $[16,17]$.

Apart from these visible features, grasslands are also defined by specific growth conditions: there is "sufficient moisture for grass growth" and "environmental conditions, both climatic and anthropogenic, [which] prevent tree growth" [18]. The occurrence of grasslands is therefore coupled to recurrent disturbances, which lead to an advantage and the establishment of grassland species. The most important disturbances in this regard are herbivory and fire [19].

Due to a global distribution and heterogeneity, there are various terms used for grasslands. Widely used terms, which are associated with grassland management, are rangeland and pasture(land). Rangelands are usually used for grazing livestock and pasture(land)s for forage production and harvest by grazing, cutting or both [20]. A bit more separated from these two terms are meadows, which are usually used to produce hay and silage [20]. There are other terms associated with grassland, which emerged locally, that are associated with local legal connotations [17] or require certain geographic site conditions, such as campos, cerrados, llanos, pampas, prairies, savannas and steppes [20]. However, these are not necessarily only covered by grassland and other forbs. For example, savannas are often a transition area between grassland and forest. Apart from that, savannas are a specific vegetation type, characterized by tropical or sub-tropical climates [16]. Therefore, savannas are not included within the review of grassland production and management using remote sensing data.

Another widely used differentiation occurs between natural and non-natural grasslands. Natural or native grassland is understood as being influenced naturally by climate, fire and native grazers [16,19]. Non-natural, managed or cultural grassland is influenced and shaped by human action [16,19]. However, most grasslands are somehow influenced by humans and the degree can vary strongly. This differentiation should therefore not be considered as strictly separable classes, but rather as a transition range. At the end of this range might be the planted grassland, which is used comparable to an agricultural crop [16]. 
Within this review, the focus is on managed grasslands, pastures and meadows.

\subsection{The Distribution of Grasslands}

The world's grasslands range from cold continental climate to tropical climates at the Equator and occur in various altitudes (Figure 1 and, e.g., [16]). As mentioned above, there are various types of grasslands globally, which are heterogeneous in their composition and physiognomy. It is therefore a difficult task to draw boundaries around grasslands and map them globally. Ramankutty et al. approached this by combining Moderate Resolution Imaging Spectroradiometer (MODIS) and Satellite Pour l'Observation de la Terre (SPOT) vegetation sensor data with agricultural inventory information [21]. The resulting map shows managed grasslands and pastures for the year 2000 (Figure 1). This map includes areas covered by savanna, which are not included in the review due to their large difference to other grasslands. Excluding the savannas, the pasture map [21] well with the focus on managed grasslands and pastures of this review. Large, continuous grasslands can be found in North America (known as the Great Plains), some parts of South America, in Europe, at parts in central and in the south of Africa, in southeastern and southwestern Australia and New Zealand and in large parts of Central Asia (Figure 1 and, e.g., [16]).

Grasslands are permanently at risk of being converted into cropland, especially in industrialized areas [2,3]. As a consequence of multiple conversions in the past, grasslands mainly occur in areas where intensive cultivation is not possible due to unfavorable site conditions, such as waterlogging, steep slopes or aridity, among others [7,19]. 

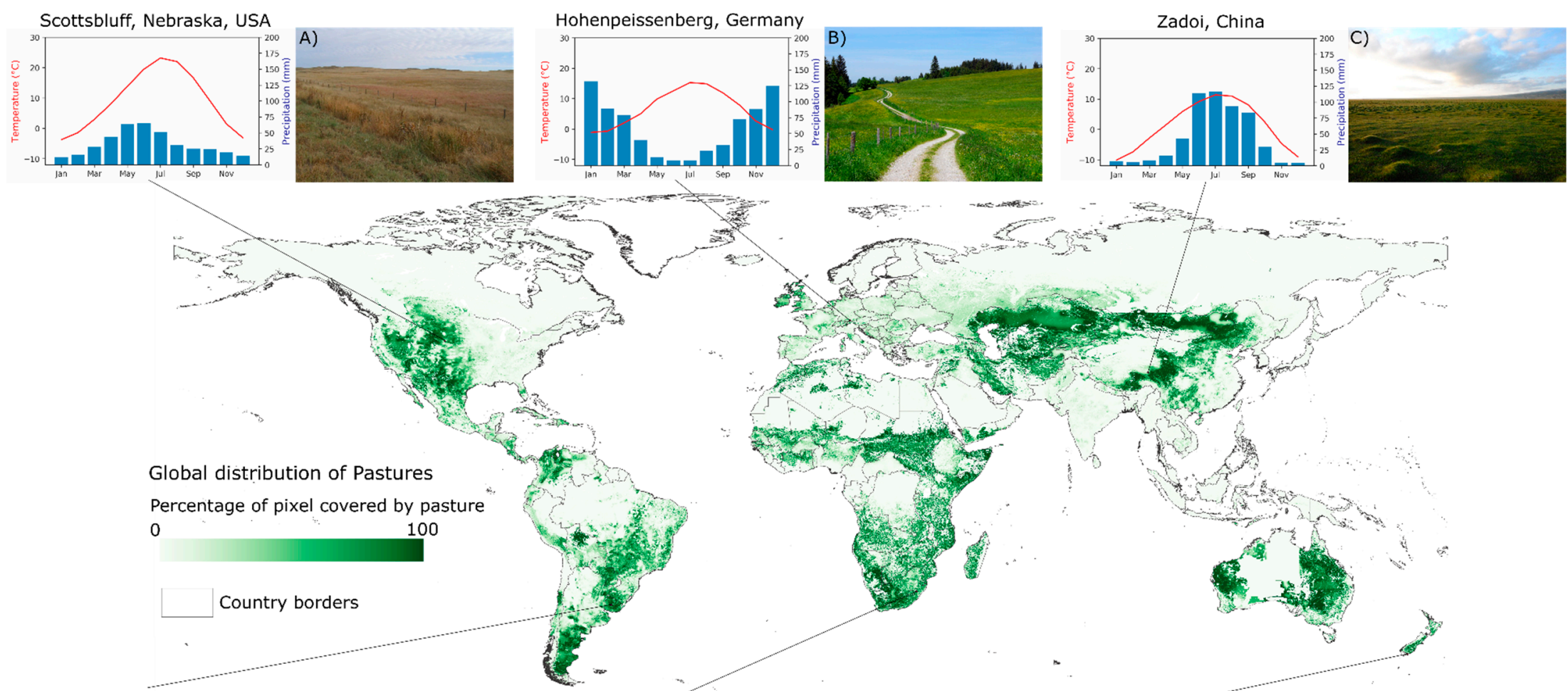

$-10 . \sum_{\text {lan }} \sum_{\text {Mar }}$

w

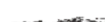

$+3$

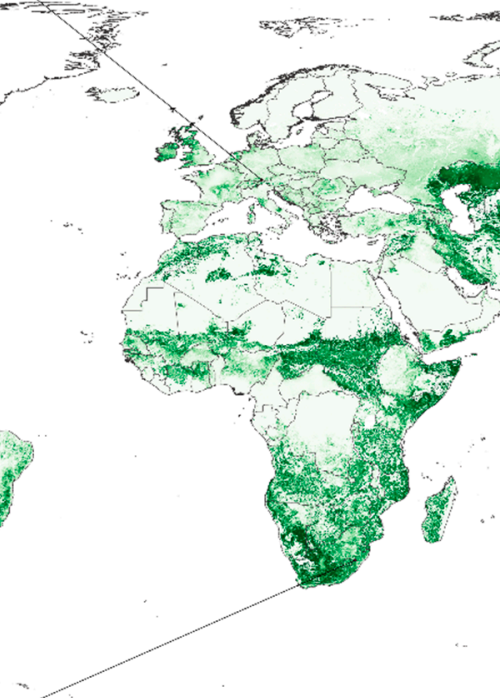

4 ar

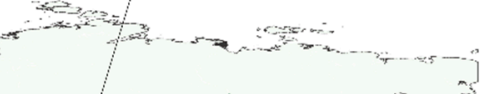

Paso de los Toros, Urugay

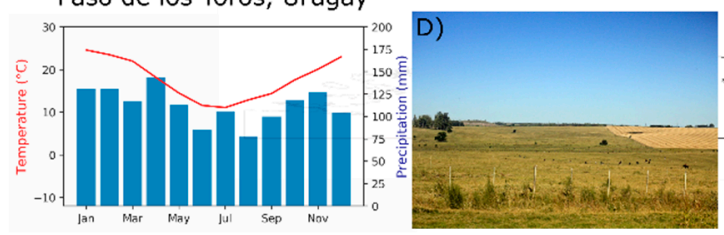

Estcourt, South Africa
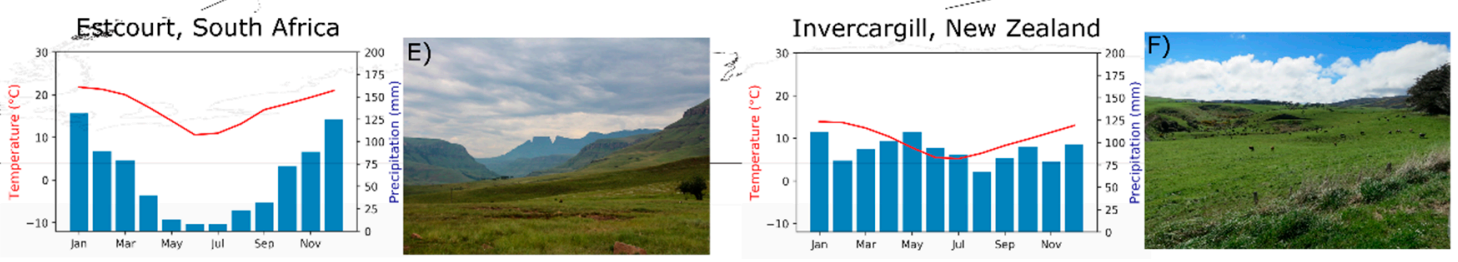

Figure 1. Global distribution of pastures (Source: NASA Socioeconomic Data and Applications Center (SEDAC) Pasture map [22]). Six climate diagrams showing annual mean temperature and precipitation of meteorological stations where grasslands are present (Source: NOAA [23]; the reference periods, from which the means are calculated, for all diagrams are around 30 years between 1960s and early 2000s). These are exemplifying climate diagrams, which indicate the high diversity of climates enabling grassland biomes but are not exhaustive. Images from the same area as the stations (Source: Flickr (www.flickr.com); more detailed information in Supplementary Table S1) 


\subsection{Grassland Management and its Effects}

As there are different types of grasslands, the management practices also differ [19]. The most widespread use of grasslands globally is livestock production, including cattle, sheep, goats, horses, water buffalo and camels [3,24]. Livestock production is often conducted via grazing or by harvesting of the grassland to provide fodder for the livestock either as hay or silage [3]. Grassland harvesting plays a major role in Europe, but it is also a common management tool in North America, Australia and China $[3,25]$. Next to fodder production, mowing is also applied to trigger the growth of grass species and reduce the number of herbs and woody plants [3]. It cannot be seen as a surrogate to grazing, as it is non-selective. In addition, there are other management actions applied on grasslands, such as irrigation, fertilization, seeding and ploughing. Irrigation plays a major role in crop management globally, and some grasslands are also irrigated [26].

The management of grasslands determines their functioning and ecosystem services, apart from site conditions. Management actions and use intensity influence biochemical processes and fluxes between the grassland biosphere, the atmosphere and the hydrosphere. For example, it was revealed that the carbon storage of grassland soils is reduced through intensive grazing [27,28]. Apart from carbon, the nitrogen cycle is also majorly influenced by agricultural intensification [29]. One example is nitrogen leaching, which has strong negative impacts on the environment, such as aquatic eutrophication. Nitrogen leaching is caused by livestock production in systems with an excess of manure [30]. It was found that extensively used grasslands show less nitrogen leaching through changes in root and microbial nitrogen uptake [31]. Various management strategies also influence the biodiversity and species composition of grasslands [13,32]. Fertilizer application, mowing frequency and timing or different herbivores favor certain plant species [3,33], which themselves determine the natural animal species distribution. The productivity of grasslands can usually be enhanced by some management activities such as irrigation and fertilization [34]. However, these enhancements often lead to a use intensification, which is possibly followed by a degradation of the grassland [3].

Many grasslands of the world are considered to be degraded $[2,19]$ as soils are depleted and desertification processes set in. The reason for that is often a highly intensive use of the grasslands. Intensively used grasslands show additional negative environmental effects, such as nitrogen leaching or species loss. In many cases the actual state of the grassland and the type and intensity of use are not known [35]. The expanding evidence for degradation processes within grasslands already triggered political awareness and the implementation of conservation policies in various countries [36-39]. For the effective realization and success of sustainable management and production strategies-for example the Common Agricultural Policy (CAP) in Europe [40]. Thus, large area monitoring and information on management and agroecological parameters are needed. In addition to the often-unknown management and state of grasslands, the production of fodder is mostly not quantified, as it is usually not a sold good, but used in farms directly. Therefore, the production loss due to changing climates, extreme events, such as droughts, or pest outbreaks is not easily quantifiable.

\subsection{The Role of Remote Sensing in Grassland Monitoring}

Conventional methods to monitor grassland production and management include field measurements or statistics, which are usually based on information from farmers. The used field measurements include biomass harvesting, eddy covariance tower measurements, field spectrometers and phenocams [41], among others. In addition to these methods, green vegetation can be monitored continuously using its spectral reflectance properties acquired by remote optical sensors ([42] and references therein). The utilization of satellite information is of high value in particular when large and/or remote areas are studied. Thus, expenses for extensive field campaigns can be reduced, objective datasets can be acquired, and easily reproducible study designs can be accomplished. Optical sensors can be used to acquire information on the greenness, vitality and density of vegetated areas. Apart from multi-spectral optical sensors, such as Advanced Very High Resolution Radiometer (AVHRR), MODIS, the Landsat fleet and Sentinel-2, which are commonly used, there are also 
spaceborne hyperspectral sensors, such as Hyperion or CHRIS/Proba. Hyperspectral data can be exploited to retrieve biophysical and biochemical variables of vegetation, and has the advantage of a higher spectral resolution [43-45]. Next to optical sensors, information on vegetation height and canopy structure [46,47], soil attributes, surface roughness [48] and dielectric properties [46,49] can be captured by Synthetic Aperture Radar (SAR) sensors (e.g., TerraSAR-X, Sentinel-1), either by using the backscatter signal, interferometry or polarimetry. The use of remote sensing data therefore enables gaining information on the quantity and quality of grasslands on large spatial scales, partly in an automated way. Furthermore, grasslands potentially reveal high intra- and inter-annual variabilities, especially where human induced intensification occurs. These variabilities are best monitored by using repeated satellite information with a medium to high temporal resolution. In addition, the spatial resolution of the sensor plays an important role. There are relatively small grassland parcels (smaller than 1 ha), especially in intensively used landscapes, and monitoring these requires spatially detailed satellite information.

Here, we focus on quantitative grassland traits and grassland use. Quantitative traits of grassland production are important parameters to evaluate the state and the ecological and economic value of grasslands. These are closely interlinked to the management and use strategies applied on grasslands. These production traits usually include quantitative parameters, such as biomass and yield, and/or a temporal information of quantitative units, such as productivity, which is defined as mass unit per area per time [20]. Within the research on remote sensing of grassland production, these quantitative traits are often not strictly separable, and the terms are not used uniformly. Therefore, grassland production traits are also assessed combined here.

Figure 2 illustrates the important components of satellite-based monitoring of managed grasslands. Optical sensors require sunlight (here, for example, Sentinel-2), while SAR systems send out a signal and receive the backscattered complex information (here, for example, Sentinel-1). Grasslands are characterized by vegetation growth cycles. These depend on the climate, site conditions, and on the management. The most prominent management strategies, i.e., grazing, mowing, irrigation and fertilization, are illustrated within Figure 2. On the right side (Figure 2) quantitative grasslands traits, such as biomass and productivity, are illustrated. The overarching arrow highlights the importance to use multi-temporal satellite data to detect the inter- and intra-annual patterns of grasslands.

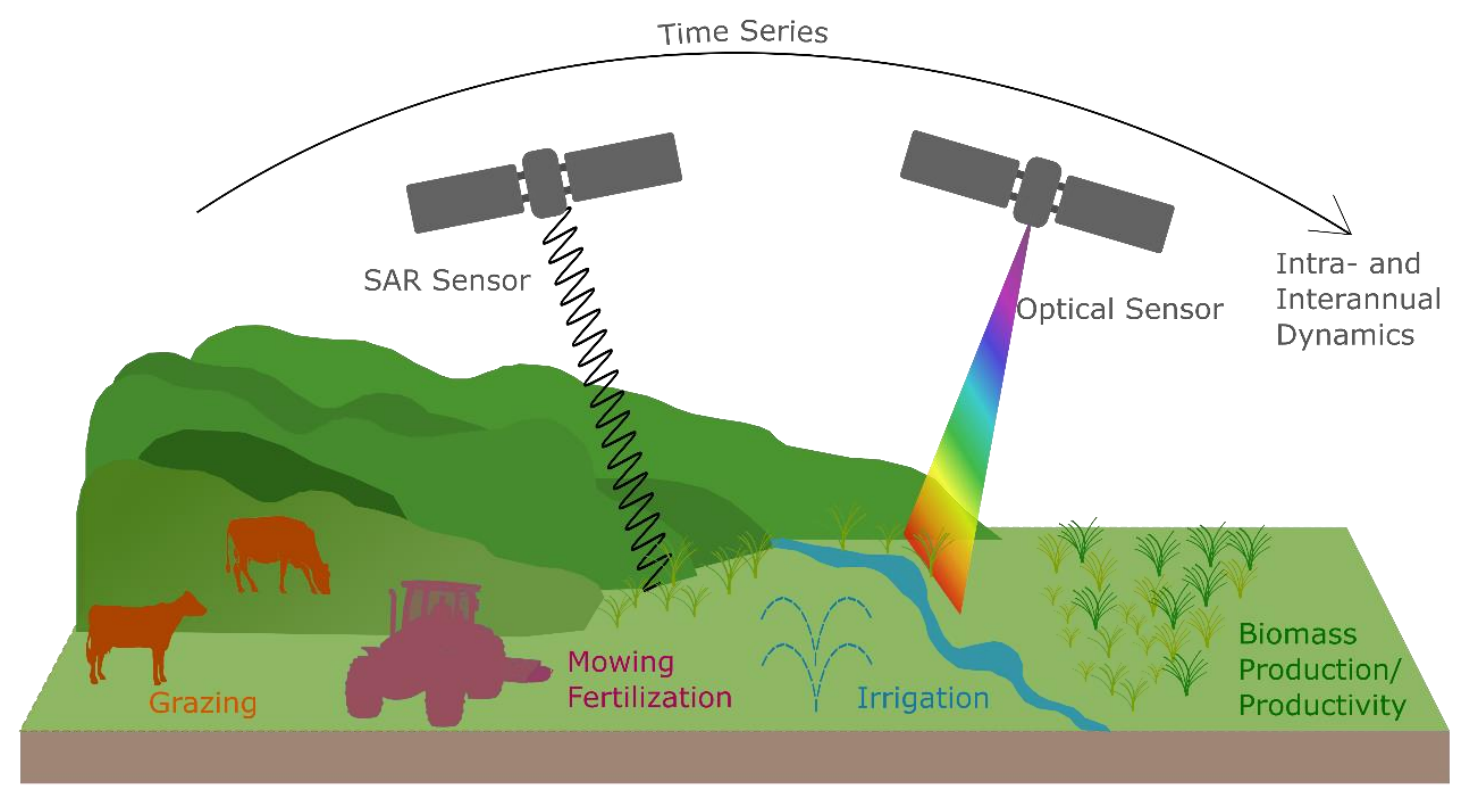

Figure 2. Overview of satellite remote sensing (optical and SAR) of major drivers and processes in managed grassland ecosystems. 


\subsection{The Objectives and Structure of this Review}

The aim of this paper is to review, structure and assess the existing research on the use of satellite remote sensing to investigate grassland production traits and management of grasslands globally. In the past, there have already been some reviews on different topics of remote sensing of grasslands [50-58]. The launch of the sensors Sentinel-1 and Sentinel-2 in 2014 and 2015 triggered research activities in the field of remote sensing of grassland production and management, which has not been covered thus far in a review. In addition, here, we assess not only the methods used but also the study regions distribution, the use frequency of sensors and indices and the development of study periods among the reviewed research. The focus of this review lies on managed grasslands and pastures. Research on remote sensing of grassland management and use intensity increased in recent years as it became more feasible due to the availability of higher resolution satellites. Special emphasize is, therefore, given to the current status of methods and results in this field. This review complements the existing literature by assessing studies in the field of optical and SAR remote sensing of grassland production traits and management, and by highlighting gaps in the conducted research.

\section{Materials and Methods of the Review}

A systematic literature research was conducted using the search engines Google Scholar and Web of Science. The search engines were checked for research articles on remote sensing of grassland production and/or management by using these key words and synonyms as search terms. A description of the search terms can be found in Table 1. In addition, the literature that was cited in the reviewed papers and literature citing the reviewed articles were also studied and included in the review when fitting thematically. The literature resulting from the search was screened and only included when it fulfilled the following criteria:

- The research articles had a clear focus in grasslands.

- The research articles analyzed quantitative traits of grassland production (such as biomass or productivity) and/or investigated grassland management strategies or use intensities.

- The research articles used spaceborne earth observation data.

Table 1. Indication of terms and search strings used for the systematic literature review.

\begin{tabular}{|c|c|}
\hline Search Aspect & Synonyms/Search Terms \\
\hline Management and Use Intensity & 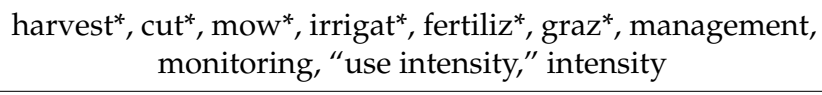 \\
\hline Production Traits & biomass, production, productivity, quantity, yields \\
\hline Grasslands & grassland $^{*}$, pasture ${ }^{*}$, meadow $^{*}$, steppe ${ }^{*}$,rangeland ${ }^{*}$ \\
\hline Remote Sensing & "remote sensing," "earth observation," satellite* \\
\hline
\end{tabular}

There were no restrictions made regarding the publishing date, the study area or the type of journal. This resulted in 253 papers, for which a list is available in the supplementary Supplementary Table S2.

All papers were reviewed and information on the study period, the study region/site, the used sensors and parameters, the type of dataset, the methods, the aim and the main findings were collected. A more detailed review was then conducted of those papers, which investigated the management of grasslands with remote sensing data. This included studies about the general management types, the intensity of use and/or the frequency and timing of management action (i.e., mowing, irrigation, fertilization). These papers were, additionally to the above-mentioned characteristics, reviewed regarding the size of the study area, conducted field campaigns and detailed processing, methodological and validation approaches. For this detailed review-in contrast to the 
broad review-conference papers were also considered in order to include all conducted research on this narrow topic. A total number of 80 papers were reviewed in detail in this respect.

\section{Results of the Review}

\subsection{Overview of Remote Sensing for Biomass, Productivity and Management}

Of the 253 papers that were reviewed, $70 \%$ investigated grassland production, $18 \%$ were dealing solely with management and use intensities and $12 \%$ had more than one of these topics. The most frequent journals were International Journal of Remote Sensing (35 studies), Remote Sensing (30 studies), Remote Sensing of Environment (21 studies) and Ecological Indicators (16 studies).

\subsubsection{Temporal and Spatial Patterns of the Reviewed Studies}

The temporal development of the number of papers is examined along with their topic proportions (Figure 3). The differentiation of study topics was made according to the main objective of the study. However, these are often interwoven, as the management intensity is sometimes examined by certain biomass or productivity patterns, for example. Studies with more than one topic are counted multiple times.

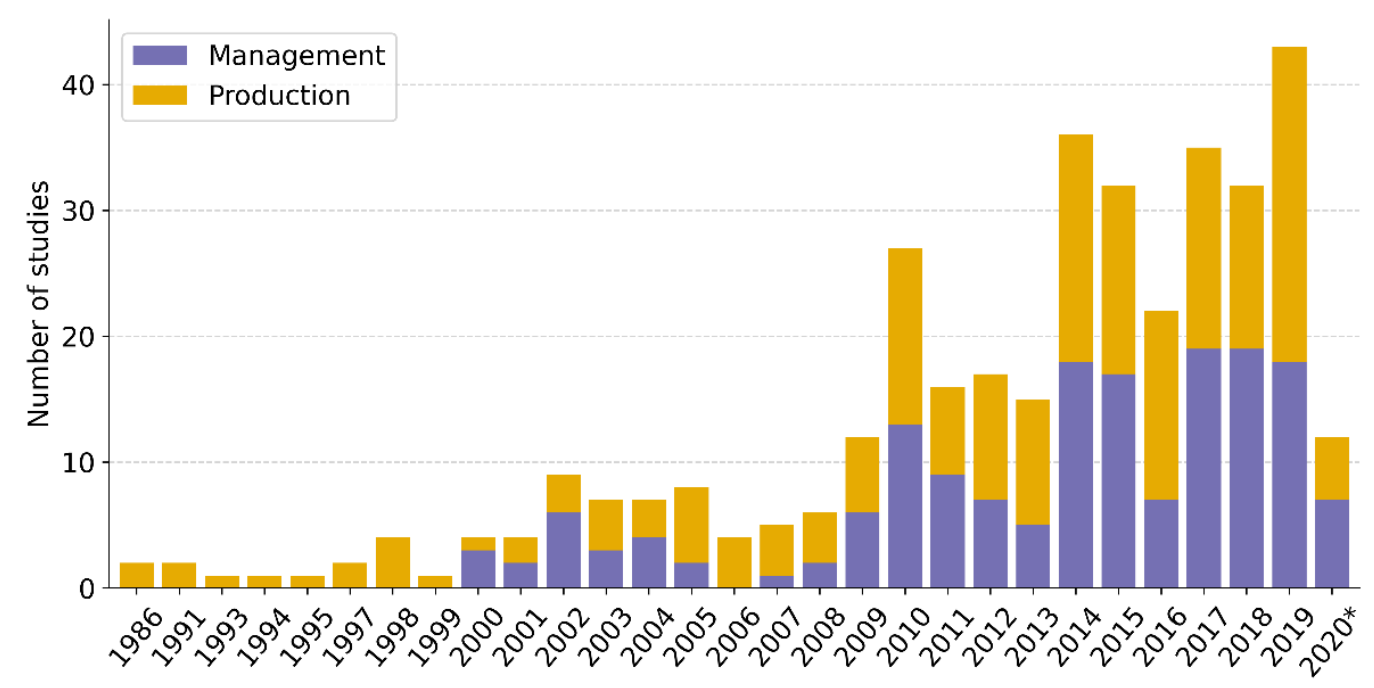

Figure 3. Annual counts of the reviewed studies including the proportions of the three main topics. Years without any studies are not shown. *Only studies published until the end of April 2020 are included.

The global distribution of the location of the study sites is investigated on country level (Figure 4). Studies with test sites covering more than one country are counted multiple times. There were two studies investigating Europe and six global analyses. These are not included in Figure 4. In addition, the varying proportions of the investigated topics are displayed per continent. The most study sites by far are located in China, which counts 89 studies. Considering the proportions of study topics, Europe shows a large ratio of studies investigating grassland management strategies and use intensities, followed by Australia and Oceania. The other continents reveal a large majority of studies on grassland production traits by investigating remote sensing data (more than two thirds). 


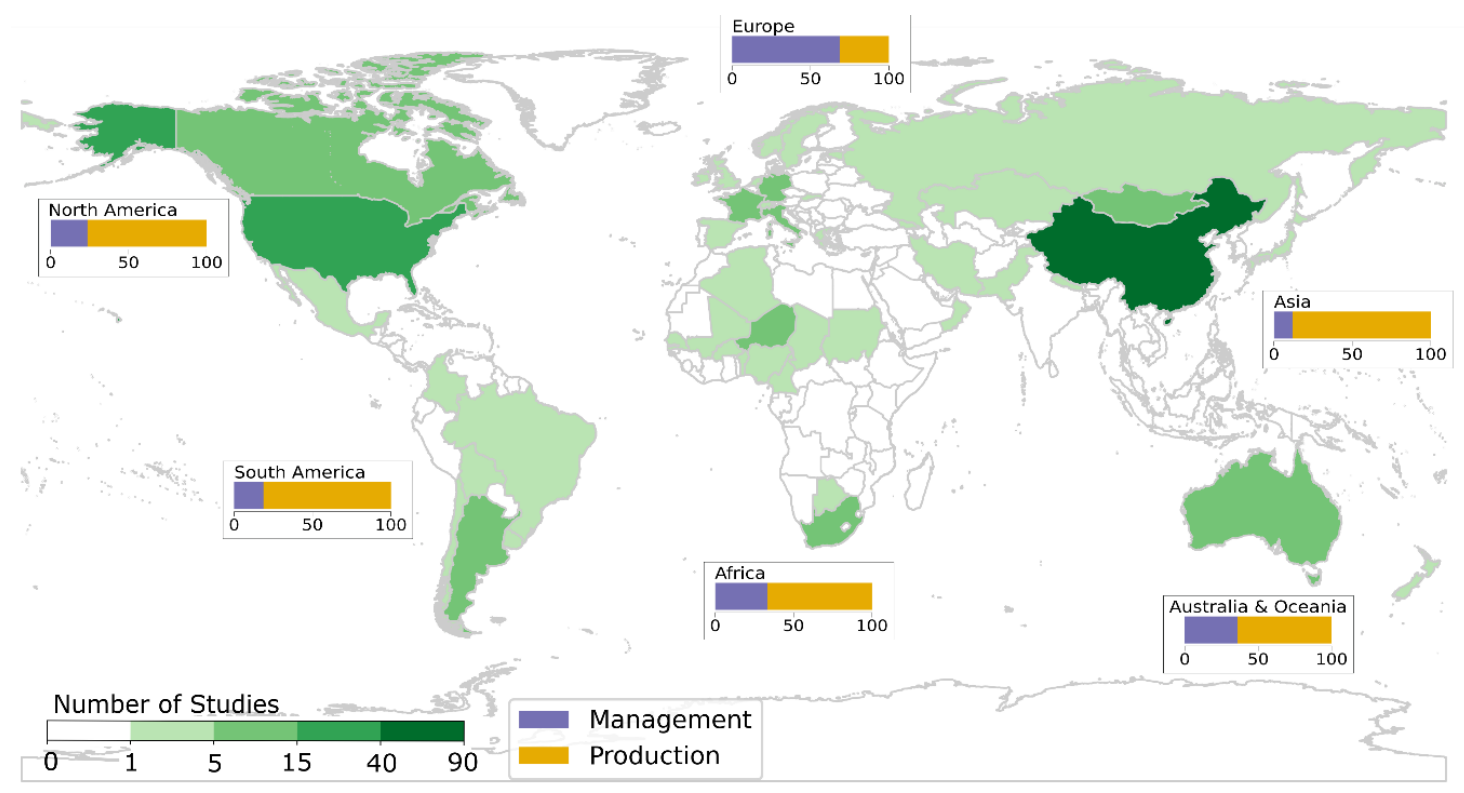

Figure 4. Number of studies per country and proportions of study topics in percent per continent.

The study periods of the reviewed articles are examined by showing the starting year, ending year and the length of used time series (one or multiple years), as well as multi- and single-image analyses (Figure 5). Multi-temporal studies are defined as consisting of at least five satellite images covering the same area. In general, many studies investigated multi-decadal satellite data time series to gain knowledge on grassland production and management, as there are multiple studies with study periods reaching back until 1981/1982. Studies focusing on grassland management strategies and use intensities less often use (longer) time series. Many study periods of all reviewed papers start in 1999, which is also the launch year of Landsat-7 and the Moderate-Resolution Imaging Spectroradiometer (MODIS) Terra satellite.

\subsubsection{The Used Sensors of the Review Studies}

Mostly optical sensors were used in the reviewed studies (Figure 6), also when having a closer look on the two main topics, production and management. Examining the used sensors and sensor fleets (Figure 7) reveals that MODIS (Terra and Aqua) and Landsat fleets were mostly applied in the past with 103 and 70 studies, respectively.

\subsection{Methods and Results of Remote Sensing of Grassland Production}

\subsubsection{Investigating Grassland Production Using a Vegetation Index as Proxy}

Vegetation indices based on optical sensors were used as proxies to investigate spatial and temporal patterns of grassland production among many studies. Several indices, which usually rely on the near-infrared and red band among others, were calculated and visually inspected [59-68]. The Normalized Difference Vegetation Index (NDVI) was by far the mostly used index in that regard. By investigating vegetation indices of multiple time-steps trends and long-term patterns, for example the effects of conservation plans were derived.

\subsubsection{Mapping Grassland Production Using a Vegetation Index and Ground-Truth Data}

Apart from a qualitative and visual examination, vegetation indices were often compared and correlated to ground-truth datasets to investigate their relevance for grassland production. Typical ground truth-datasets of grassland production analyses were biomass samples or eddy covariance tower measurements [41]. Zhou et al. [69] correlated several vegetation indices based 
on MODIS data to eddy covariance measurements and found a high significance of the Enhanced Vegetation Index (EVI) when the vegetation cover was high. For low vegetation cover, the Soil-Adjusted Vegetation Index (SAVI) showed the best correlation to the eddy tower measurements [69]. In addition, it was revealed that the relationship between a satellite-based greenness index and eddy covariance measurements was not constant among various timescales [70]. The greenness index seems to react slower than the production measured with eddy covariance towers at short timescales.

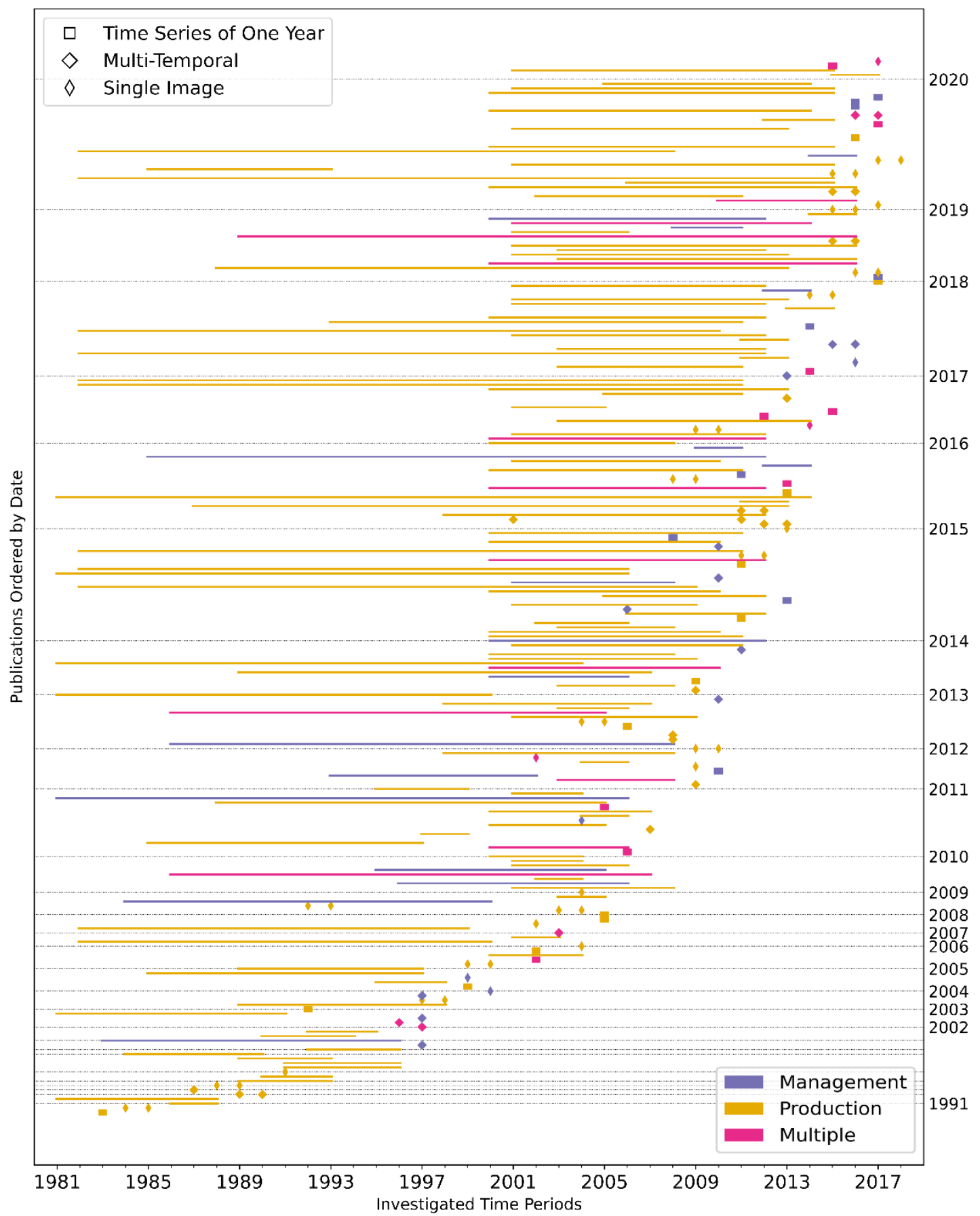

Figure 5. Investigated study periods ( $x$-axis) for every publication ( $y$-axis, not discrete). Multi-annual studies are indicated by lines and studies conducted in one year by the specific symbols. The colors represent the different study topics. The dates on the right $y$-axis show publication years of the studies. 
All topics -

$$
0
$$

50

100

150

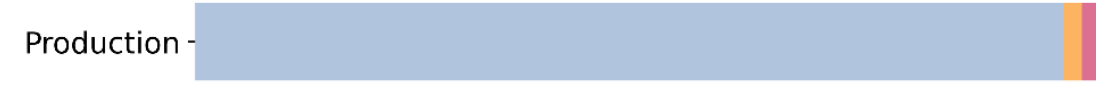

Optical

Radar

Both

Management
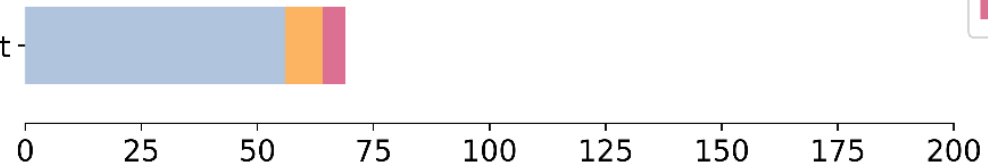

Figure 6. Counts of studies using optical or radar sensor systems or both for all reviewed studies and for the specific topics each. Studies with multiple topics were counted several times.

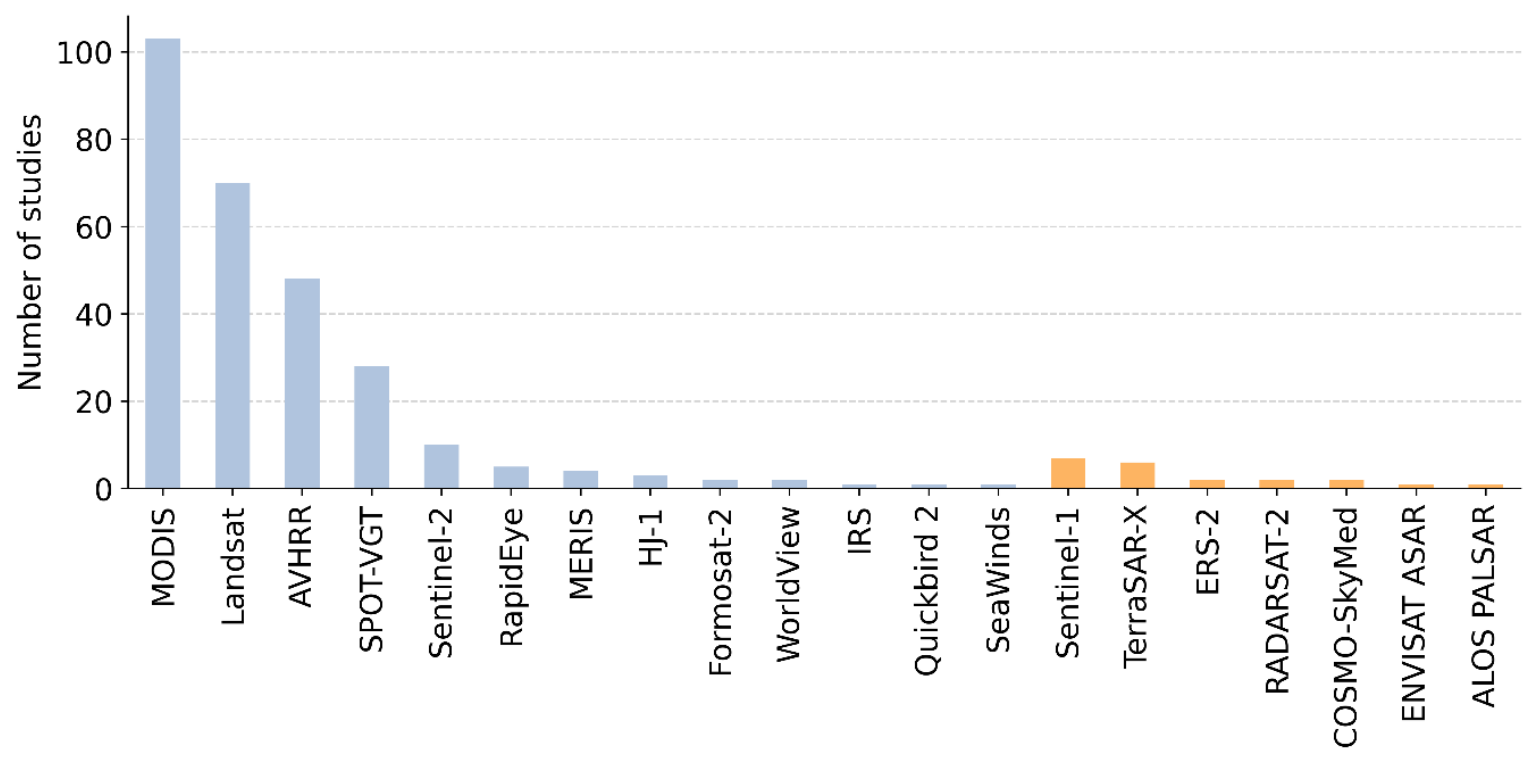

Figure 7. Counts of sensors and sensor fleets used in all of the reviewed studies. Studies were counted several times if more than one sensor was used.

In order to map grassland production, empirical relationships between ground-truth data and vegetation indices were investigated and empirical models were built. Based on eddy covariance measurements and other biophysical variables, grassland production was estimated per week by using a regression tree approach [71], which revealed the potential of grasslands to serve as a carbon sink.

Apart from eddy covariance measurements as ground-truth variable, biomass samples were often used to train an empirical model in order to map grassland production. In $62 \%$ of the studies investigating grassland production using biomass samples and remote sensing data, the NDVI was at least one of the indices tested as model input. The EVI (15\%), the SAVI $(9 \%)$ and the Leaf Area Index (LAI) (8\%) were also utilized often within satellite data-based biomass models. The empirical relationship was mostly created by using a simple linear or multiple linear regression $(60 \%$ of studies using biomass samples) [72-74]. In addition, in some cases machine learning-based regression methods were tested to estimate biomass, such as Random Forest [75-78], Support Vector Machines [79], Generalized Linear Models [80], Gaussian process regression [81], Artificial Neural Networks [82-88] and Adaptive Neuro-Fuzzy Inference Systems [83]. The biomass models among the reviewed papers show a high range of accuracies with $\mathrm{R}^{2}$-values of 0.4 to 0.97 (Figure 8 ). The highest $\mathrm{R}^{2}$-values (above 0.95 ) were reached when restrictions were made to reduce the temporal or spatial heterogeneity of the 
target variable. For example, the investigated area was pre-filtered according to grassland cover types or only a certain time in the year was investigated [89,90].

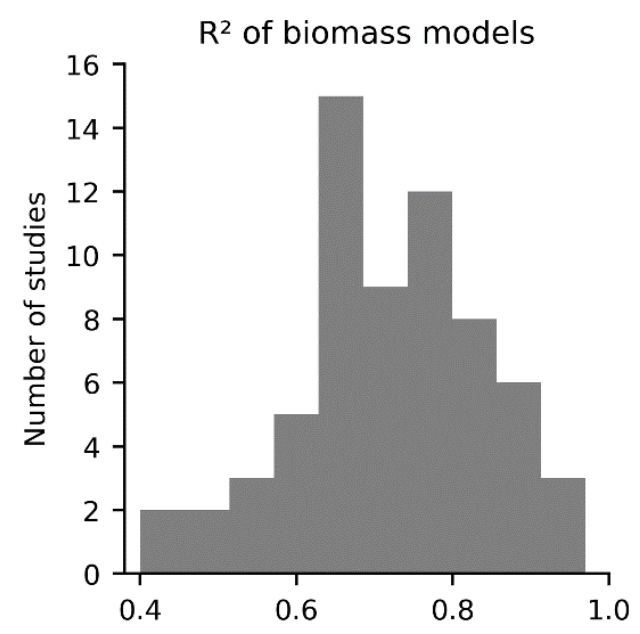

Figure 8. Frequency distribution of $\mathrm{R}^{2}$-values for biomass models built with remote sensing data and field data as training variables.

\subsubsection{Using a Modelling Approach to Estimate Grassland Production}

Radiative transfer models were usually used to estimate quantitative, bio-physical parameters of grasslands, such as biomass or productivity. Based on the LAI, derived from the radiation transfer model PROSAIL, biomass was estimated in [86]. The PROSAIL model is a combination of a leaf optical properties (PROSPECT) and a canopy bi-directional reflectance (SAIL) model and is frequently used to derive bio-physical properties of vegetation [91]. Another example of a modelling-based derivation of grassland yield is the application of the crop growth model STICS (Simulateur mulTIdisciplinaire pour les Cultures Standard), e.g., [92].

A large majority of the studies investigated grassland productivity, usually a mass unit per area per time, based on satellite data using a light use efficiency (LUE) model [93-96]. The variant, which was mostly used among the reviewed studies, is the CASA (Carnegie-Ames-Stanford Approach) model, e.g., [97,98]. Within the CASA model and generally within LUE models, the productivity is calculated as a function of absorbed photosynthetically active radiation (APAR) and the LUE. The APAR can be derived from optical sensor-based vegetation indices for certain vegetation types [99]. Another LUE-based model used by the reviewed articles is the Vegetation Photosynthesis Model (VPM), e.g., [100], which is relatively similar to the CASA model, but differs in the approach of estimating the LUE [101]. Other process-based models, which were used to estimate productivity of grasslands with remote sensing data are the BIOME-BGC [102], C-Fix [103], DeNitrification-DeComposition (DNDC) [104], Global Production Efficiency Model (GLO-PEM) [105], Temperature and Greenness (TG) model [106], Greenness and Radiation (GR) model [106], Eddy Covariance-Light Use Efficiency (ECLUE) model [106], Vegetation Production and Respiration (VPRM) model [106] and the Organizing Carbon and Hydrology in Dynamic Ecosystems (ORCHIDEE) model [107]. While comparing some of these models for estimating grassland productivity in China, Jia et al. [106] found the LUE-based model ECLUE to perform best. These model-based grassland production estimations were often validated by comparing them with eddy covariance tower measurements [107-112].

\subsubsection{Analyses of the Influencing Factors on Grassland Production}

Various regional and temporal patterns and trends of grassland production were analyzed, and the effect of climate was studied. Precipitation showed to be a major determining factor for grassland production [60,113-116]. Especially during early and mid-growing season, positive correlations were found between precipitation and grassland production. However, the timescales of sensitiveness 
of grassland production to precipitation varied among different grasslands from daily to monthly and seasonal [117]. Temperature was mostly negatively correlated to grassland production [118,119]. In addition, the influence of temperature on grassland production was found to change during the season, with the highest effects at the beginning of the growing season [120]. For some grasslands, the effect of temperature on grassland production was dependent on recent precipitation [60] or soil moisture content [121]. When plant available water was sufficient, higher average growing season temperature showed a positive effect on grassland production [121]. When comparing census data, which is related to human activity (e.g., stocking rate) and grassland production, in most cases an existing relationship was revealed [97]. Compared to the influence of climate, human activity was found to have a larger [119] or a smaller $[115,122,123]$ influence on grassland production.

\subsection{Detailed Review of Studies on Remote Sensing for Grassland Management and Use Intensity}

3.3.1. Management Type, Study Areas and Parameters of Remote Sensing of Grassland Management and Use Intensity

The studies investigating the management and use intensity of grasslands with satellite remote sensing data mostly focused on the management options mowing and grazing (Figure 9). Studies investigating other strategies, including irrigation and fertilization, were almost not found. Studies in which multiple management types were investigated were counted multiple times.

Management Type

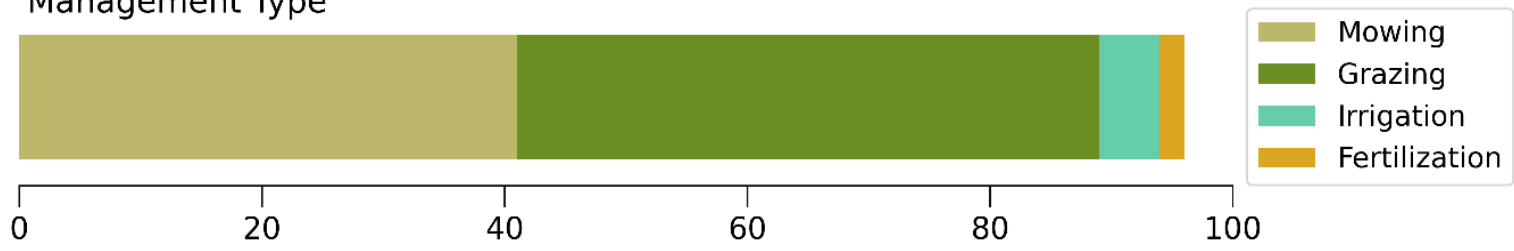

Figure 9. Number of times one of the management types was investigated within the reviewed studies.

For studies investigating grassland management and use intensity, the extents of the study areas were examined (Figure 10). For studies in which the exact size of the study area was not specified, the extent was estimated using the maps from within these studies. Studies analyzing multiple management types were counted multiple times.

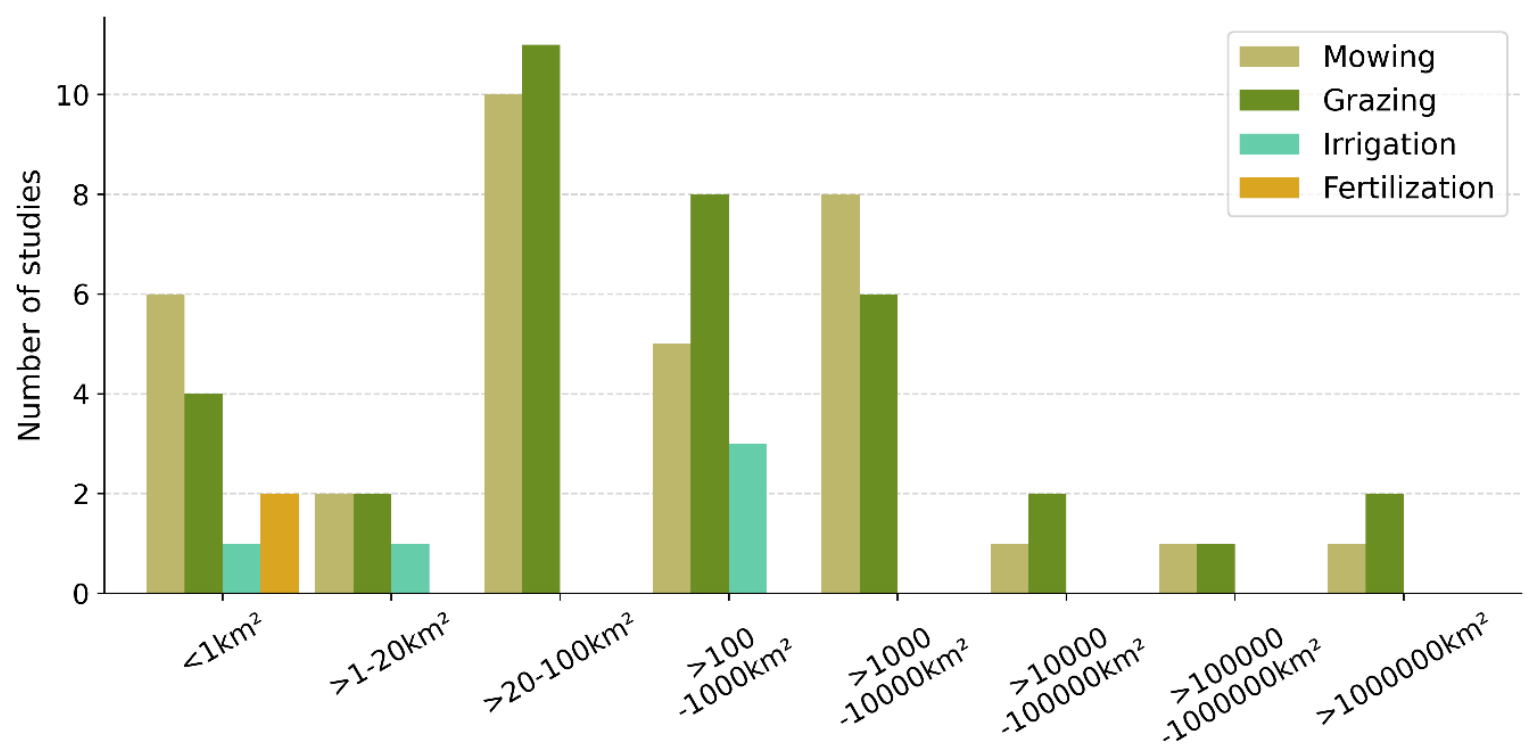

Figure 10. Extents of the study areas per management type. 
The NDVI was the most widely used (46\%) index within the studies investigating grassland management with remote sensing data. In $12 \%$, the LAI was investigated and in $11 \%$ band reflectance values were included into the studies. The EVI was analyzed in $7 \%$ of the cases and fCover in $5 \%$. The backscatter information was the most used parameter based on radar systems with an occurrence of $15 \%$ within all of the studies. In total, $6 \%$ of the studies looked into the temporal coherence calculated from interferometry. Less often occurring parameters based on optical satellites included the Fraction of absorbed Photosynthetic Active Radiation (FAPAR), Tasseled Cap components, the Normalized Difference Water Index (NDWI), the SAVI and vegetation indices based on the red edge bands of Sentinel-2. Based on radar systems, polarimetric decomposition parameters, such as alpha angle and entropy, polarimetric coherence or intensity ratios between different polarizations, were also investigated to analyze grassland management.

\subsubsection{Methods Used in Remote Sensing of Grassland Management and Use Intensity}

Various methods were applied in the context of satellite-based grassland management and use-intensity studies. They can be roughly grouped into the following categories: classifications, correlations/regression analyses and time series analyses. It was analyzed within which research focus or for which research aim these methods were applied in the reviewed studies (Figure 11). Depending on the research aim, these categories were sometimes not strictly separable, and methods were mixed to derive grassland management information.

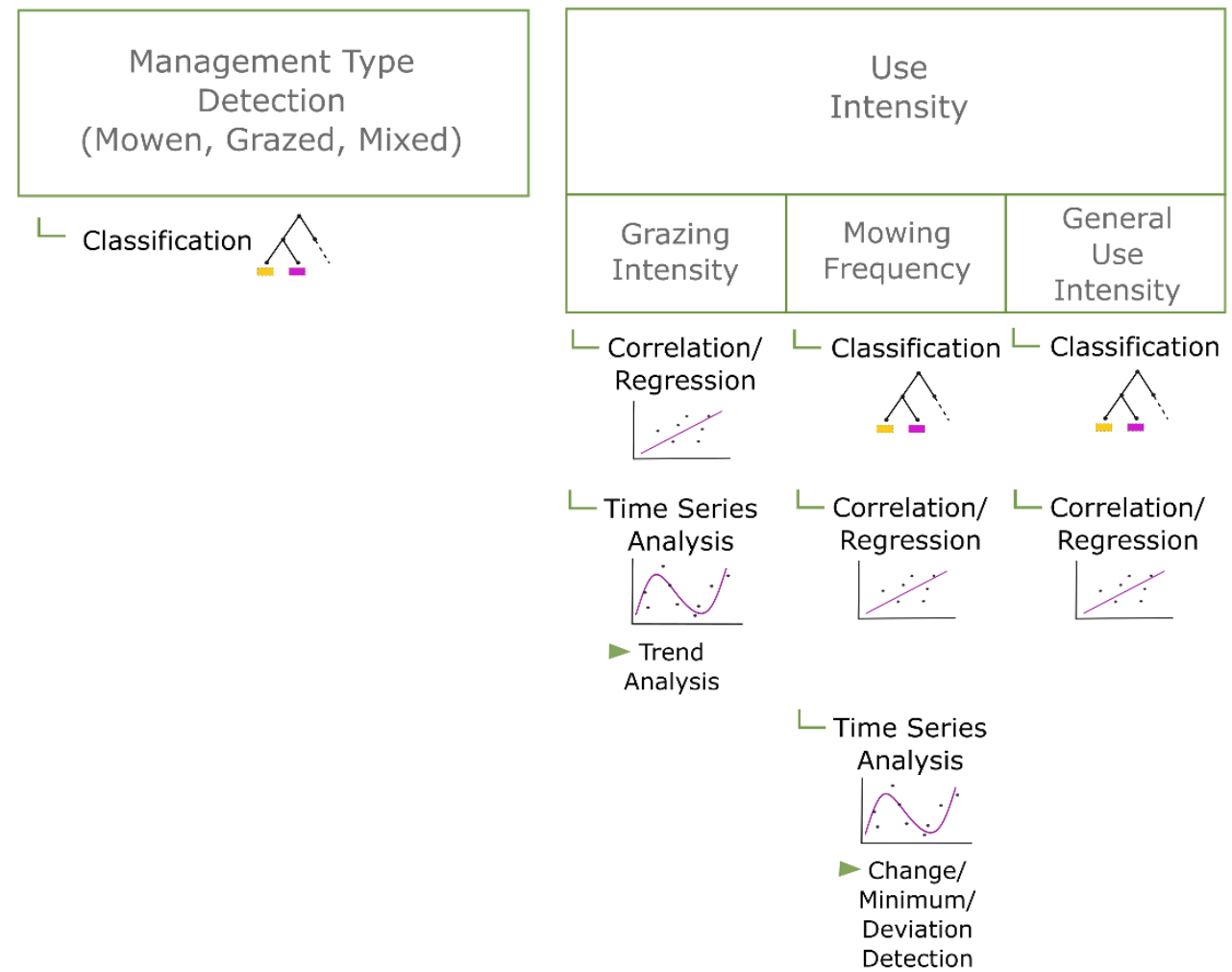

Figure 11. Overview of the methods used in studies investigating grassland management with remote sensing data, divided by the two main research aims, namely the detection of "Management Type" and "Use Intensity."

One of the most often used methods were classifications, whereas the used classifiers and the specific aims differed. Either various management strategies, such as grazing, mowing or mixed, were classified [124-126], or the focus was on the intensity and the classification was applied to detect different degrees of use intensity of the grasslands [127-129]. In studies focusing on mown grasslands, classifications were applied to detect mowing events during the growing season [130-132]. 
Regarding the classifiers, the following were already used for the purpose of grassland management or intensity classification: decision trees and random forest [127-130,133-135], K-Nearest Neighbor $[124,125,134,136]$, Support Vector Machine [124,133,136-138], Discriminant Analysis [124,126], Naive Bayes classifier [124], Neural Networks [132] and empirical decision rule-sets $[124,127,128,134,139,140]$. The satellite products used for the classification were based on both optical and SAR systems (see Figure 6). Besides the classified map result, the influence and importance of the single explaining variables were often investigated. Mostly, the aim was to differentiate the influence of human and natural impact factors and to determine the most important ones, for example precipitation or stocking rate [115,141,142].

Apart from classifications, correlation and regression analyses were undertaken to deepen the understanding of the relationship between satellite remote sensing indices or estimated biophysical parameters, such as biomass, and management or use intensity-related grassland characteristics, such as livestock density or a degradation proxy [143-148]. Multivariate statistics were applied to estimate the importance of management and use intensity-related parameters for determining the patterns of satellite-based indices and variables and to separate them from the effects of site conditions $[115,149]$.

Another important methodological approach was the temporal analysis of satellite-based information to extract dynamical processes of grasslands, such as mowing events or different grazing patterns. In more explorative studies, time series of remote sensing parameter were visually examined and the temporal patterns before, during and after specific events were compared and correlated to each other and to field data [150-158]. Trends of indices or biophysical parameters derived from satellite data were analyzed, in particular to reveal grazing intensity patterns $[25,64,115,147,159]$. For the detection of mowing events, time series data played a crucial role as specific temporal patterns, usually a change, local/global minimum or deviation, were analyzed [160-163].

In the following, the approaches, results and validation of remote sensing-based studies on grassland management are outlined according to their main research aim.

\subsubsection{Results and Validation of Studies on Remote Sensing of Grassland Management and} Use Intensity

\section{Management Type Detection}

One central aim of satellite-based remote sensing of grassland management is the detection of the applied management type. Mostly, a classification was applied, and three classes were distinguished: (frequently) mown, grazed or a mixture of these two. The best obtained results using a classification approach reveal a kappa value of 83\% [125] (Time Dynamic Warping, Landsat-TM and SPOT-4). In order to detect the management types, the LAI—estimated using the PROSAIL model—showed to be an important input parameter [124]. The incorporation of radar backscatter data did not improve classification results in two cases [124,126]. In addition, it was revealed that cloud-free observations in spring and early summer are important to successfully classify the management types $[164,165]$. In particular, this can improve the detection of the mixed class, which is in general not easily differentiated [164]. Thus far, the research focus was on mowing and grazing detection, and not on other management activities such as irrigation or fertilization. Information on irrigation or water availability in general is possibly extracted from radar backscatter information as it relates to soil moisture [143].

\section{Analysis of Grazing Intensity}

Studies focusing on grazing intensity patterns used vegetation index time series to conduct trend analyses and extract regional patterns [64,85,166,167]. The grazing intensity was either defined as a proxy, e.g., a vegetation index [64], estimated from biomass information [85,168], approached statistically from livestock census data [147] or was based on field experiments $[167,169]$. 
When grazing intensity was based on livestock data it was usually defined as animal per area $[167,169]$. In some studies, land allocation algorithms were applied to generate spatial information on livestock densities from lower resolution census data, e.g., [170].

With the aim to detect grazing intensity, optical sensor-based vegetation indices were in the focus of investigations $[115,150,167,169]$. There were significant relationships found between the NDVI and grazing intensity measures based on field experiments $[167,169]$. Within these studies, there were positive and negative trends of grazing intensity and degrading effects revealed and conservation schemes were found to lead to improvements $[147,150,166]$. Hotspots of grazing intensity were detected close to watering ponds [150]. In order to disentangle negative vegetation effects of intensive grazing from climate impacts, grassland biophysical parameters (canopy cover, biomass) or condition indicators (NDVI) were correlated with livestock density and meteorological data, or multivariate analyses were conducted $[115,144,147,150,171]$. The results of the effect of stocking rate in that regard were mixed, as both significant and insignificant relationships to grassland characteristics were detected [115,144,147].

\section{Mowing Event Detection}

Another closely related research aim applying remote sensing data for grassland management studies is the detection of mowing dates. When a classification approach was used, the satellite spectral or SAR information of the grassland was distinguished between cut and uncut. Siegmund et al. [135] reached an overall accuracy of $91 \%$ for mowing detection using Sentinel- 1 backscatter and temporal coherence data. The recall was however low and the total F1 score was at $55 \%$. Focusing on intensively used grasslands, Taravat et al. [132] adapted an artificial neural network on SAR-based backscatter and texture metrics and resulted in an overall accuracy of $85 \%$ for two test sites. The texture metrics were more important input variables than the SAR backscatter signal. A classification of optical sensor-based vegetation indices resulted in an overall accuracy of $85 \%$ for only extensively used grasslands [130]. Rule-based change detection approaches applied on SAR backscatter data lead to successful detections of cutting events, for example, in Grant et al. [172], 72\% of the events were detected. Even though datasets of the entire growing season were included in the classifications, the temporal information was usually not considered within these methods.

A time series analysis approach, based on a temporal decision ruleset, led to an $\mathrm{R}^{2}$ of more than 0.9 of successful mowing detection when compared to ground data [160]. The investigated grasslands in this case were relatively homogeneous and were all characterized by three mowing events per year. Kolecka et al. [163] reached an overall accuracy of $77 \%$ of correctly detected mowing events by identifying abrupt drops in a NDVI series dataset. Additionally, with the approach of detecting local minima in a NDVI series, Estel et al. [161] used the detected mowing events to calculate the mowing frequency, which had an accuracy of $80 \%$. Griffiths et al. [162] approached the detection of mowing events for Germany, resulting in a heterogeneous compilation of managed grasslands. They only conducted a qualitative evaluation of their results.

The SAR-based backscattering information showed differences in the amplitude during mowing events [172], but there was no significant relationship found between the backscatter and biophysical properties of grasslands [158]. The coherence of an X-band sensor was shown to correlate both with wet above-ground biomass and vegetation height of grasslands. The expected increase of coherence after a mowing event could be depicted; however, it was not present at all times [154,157]. In addition, a strong influence of morning dew was found, especially when the radar images were acquired relatively early in the morning [154]. Considering polarimetry, the dominant scattering alpha angle decomposition parameter showed good agreement in detecting cut grass lying on the ground [155]. However, there were no significant correlations between the decomposition parameters and biophysical grassland variables found and detected patterns were not consistent [156]. 


\section{General Use Intensity}

The successful detection of mowing events and/or grazing intensity is often taken as the basis to estimate the general use intensity of the grassland [161-163,170]. With the aim to distinguish different levels of intensity, classifications were conducted [127-129,133,139]. Barrett et al. [133] reached an overall accuracy of $96.6 \%$ based on different radar sensors while classifying 10 land cover classes, which include a differentiation between different grassland intensities. Surprisingly, the ancillary data, such as slope, elevation and soil information, were more important than the satellite data. Using high spatial resolution optical data, Franke et al. [128] resulted in an overall accuracy of $85.7 \%$ when classifying four classes of different degrees of grassland use intensity. Within this study, a parameter representing the spectral dynamics was an important input variable for the classification [128]. Gomez-Gimenez et al. [170] integrated mowing frequency, grazing intensity and livestock density estimations to analyze grazing intensity in Canton Zurich, Switzerland. In a recent study, use intensity classes of grasslands were generated based on management events detected with NDVI time series [173].

\section{Discussion}

\subsection{Global Patterns, Scales and Products of Remote Sensing of Grassland Production and Management}

In almost all countries with large continuous grassland areas, there is at least one study on remote sensing-based production or management traits. Comparing the extent of grasslands (Figure 1) to the countries, in which grassland studies were conducted (Figure 4), some countries, such as eastern European countries, are completely missing. In addition, the number of studies varies a lot globally. There are grasslands for which multiple studies on satellite data-based grassland production exist, for example, the Xilingol steppe in China. Research in South America and Africa in this regard is relatively rare, even though there is no lack of grassland covered regions. Differences in the numbers of studies between grassland regions may be more related to practical issues than to the importance and value of the grasslands, for example, less research projects and activities were focused on grasslands. As a consequence, large-scale information and maps of grassland production traits and management are still not available for some countries with large grassland covered areas.

The earth's grasslands are very diverse and heterogeneous [174]. This seems to be an obstacle for the analyses based on remote sensing data. Depending on the method and the research focus, the spatial scales of the studies vary. Studies on grassland production based on LUE models are often large-scale to global. Grassland production estimations based on empirical models, which are dependent on ground-truth data, usually take place on a regional level, and grassland management and use intensity analyses are often conducted on regional or parcel level. This is probably caused by rather technical and methodological conditions. Ongoing advancements in this regard, such as model refinements, advanced machine learning algorithms or time series analyses, might change this pattern in the near future. In addition, the availability of data from high resolution satellites, such as the Sentinel fleet, improves grassland monitoring, for which mainly the Landsat and MODIS time series datasets have been exploited thus far. Apart from missing large-scale products, there is also a lack of automatized retrieval and monitoring systems of remote sensing-based grassland production and management traits.

\subsection{Assessment of Remote Sensing of Grassland Production}

\subsubsection{Assessment of the Used Remote Sensing Sensors and Indices for Grassland Production Estimation}

For remote sensing-based grassland production, such as biomass and productivity, research has been mostly focused on optical systems (compare to Section 3.1.2). The exploitation of SAR data, at least as accompanying the data source, might be beneficial, especially due to the availability of high-resolution 
SAR time series data with Sentinel-1, which is not constrained by data gaps through clouds. Radar systems have a long history in forest ecosystem research (see [175]). Moreover, within croplands, SAR data is already recognized as a valid source, not only for crop type classification, but also for the retrieval of bio-physical parameters [49]. Depending on the crop, SAR-based temporal backscatter information has already shown good agreement with the phenology of plant biomass. For example, soybean biomass was correlated (R-value 0.81) to the HV-backscatter based on C-band [176].

In addition to that, the use of hyperspectral data is most certainly increasing as there are various hyperspectral sensors launched in the near future, such as EnMap [177]. Thus far, research on production traits or management with a clear focus on grasslands using spaceborne hyperspectral data are rare. There are some explorative studies, e.g., investigating the performance of Hyperion data within a biomass model based on spectroradiometer data and biomass samples [178] or testing emulated spaceborne sensor data [179]. In contrast to spaceborne data, there are multiple studies using airborne hyperspectral data to retrieve biophysical variables of grasslands [180-182]. It was shown that by using both, empirical relationships and radiative transfer models, biophysical variables, e.g., LAI, can be successfully estimated based on the airborne sensor HyMap, even on heterogeneous grasslands [181,182]. Based on these results and in the light of the increase in available datasets, the exploitation of spaceborne hyperspectral data forms a promising research opportunity in the near future $[45,177]$.

\subsubsection{Analyses of Grassland Production Based on Empirical Relationships between Ground-Truth} Data and Satellite Data

Remote sensing data usually has the advantage of enabling large scale and multi-temporal analyses of the earth surface. However, grassland production estimations mostly require field measurements as training and validation data. This is still a major obstacle for satellite-based grassland production investigations due to its financial costs and effort, and it is a source of inconsistency between studies. In addition, the empirical grassland production models, which were calibrated with local field data (biomass samples or eddy covariance tower measurements) cannot easily be transferred into other regions, especially not into completely different grassland systems. The reason for that is a likely occurring variability in the empirical relationship between the remote sensing parameter and the grassland production trait. This variability also leads to a reduced accuracy, and thus, the explanatory power of grassland production models capturing heterogeneous grasslands. This is also reflected by the large range of $\mathrm{R}^{2}$-values of the reviewed grassland biomass models (Figure 8), which shows that biomass can be explained well by a remote sensing parameter, but that this is not necessarily the case under all site conditions and for all grasslands.

Apart from a spatial variability, there might be a temporal inconsistency within the relationship between the remote sensing parameter and the grassland production trait. This is especially the case for highly dynamic grasslands. Grasslands that are frequently mown usually show high (intra-annual) dynamics in the amount of present biomass and the productivity. As European grasslands are highly managed and often frequently mown, this might be the reason for a relatively small amount of satellite data-based studies on grassland production there. Information in grassland quantities, such as biomass, with high temporal resolution might reveal management events, and thus, account for the grassland dynamics. To build a valid model, this might need multiple field measurements during the year. This interlinkage might also work the other way around. When more or less exact information on the management activity exists beforehand, an accurate biomass time series could be built upon this. Temporal biomass information would be advantageous in order to study the effects of climate and climate change on grassland production, for example, a drought. In addition, multi-temporal biomass data would facilitate the analysis of the influence of various management strategies and their separation from climate-related fluctuations. 


\subsubsection{Estimating Grassland Production Using a Modelling Approach}

In contrast to empirical models of grassland production, which are dependent on ground-truth data (biomass samples and eddy covariance tower measurements), grassland productivity and biomass can also be estimated based on physical models. Within these models, bio-physical parameters of grasslands can be retrieved. In most cases, the grassland productivity is estimated. The productivity retrieval, mostly based on a LUE model, is more broadly applicable. There are already some global products, for example the eight-daily/monthly MODIS Net Primary Productivity (NPP) product [183]. The advantage is that analyses of global processes and interactions, such as the influence of climate on productivity, are possible with such large-scale products. Productivity and biomass estimations based on physical models do not need field measurements as model input. However, due to the heterogeneity and temporal variability of grasslands at small scales, field data-based calibration, for example with eddy covariance tower measurements, is often necessary to achieve reasonable production estimations [184-186].

4.2.4. Analyzing the Influencing Factors on Grassland Production and Productivity with Remote Sensing Data

A major research focus of studies on grassland production is the investigation of the influence of climate. This is especially important for the realization of optimal mitigation strategies for climate change. A high importance of precipitation as major influencing factor of grassland production was shown, e.g., $[60,113-115,187]$. The influence of precipitation and temperature on grassland production is relatively complex as it can change through the growing season, vary among different grasslands and determine and depend on each other $[117,120,121]$. When compared to the influence of human activity, both larger [119] and smaller $[115,122,123]$ influence on grassland production were found. The information on human activity in analysis on larger scales is usually census-based, such as stocking rate, and is therefore not a spatial information. Spatially explicit management and use intensity information, which has been mostly left unconsidered thus far, would improve the assessment of influencing factors on grassland production, and therefore enhance conservation plans.

Extreme weather events, such as droughts, also have strong negative impacts on the condition and production of grasslands, e.g., $[188,189]$. In societies that are highly dependent on livestock production on grasslands, extreme weather induced reduction in grassland production can have severe consequences for nature, economy and humans [190]. In the light of global climate change, periodic drought events will increase in some regions, and therefore, mitigation strategies are needed. Grassland resistance and resilience to drought can among other things be dependent on the management, use intensity and species richness [191].

\subsection{Assessment of Remote Sensing of Grassland Management}

\subsubsection{Assessment of the Used Remote Sensing Sensors and Indices of Grassland} Management Analysis

Considering the used satellite data for remote sensing of grassland management and use intensity, the reviewed studies revealed a high relevance of time series and especially of high-quality acquisitions in spring and early summer for temperate grasslands [165]. In this time of the year, the productivity of the vegetation and plant growth rate before and after mowing or grazing events are high. Consequently, the changes in amplitude of the spectral and backscatter signal are large, improving the detectability of management events. The majority of studies that used optical satellite data as vegetation indices, such as NDVI and EVI, showed that they represent the condition of the grasslands well $[167,169,170]$. Based on SAR data, the HH/VV ratio related well to grassland phenology [136]. In semi-arid regions, the SAVI possibly improves the analysis of the grassland condition and use intensity [145,192] due to larger amounts of soil backscattering. Even though the current grassland condition might be well monitored by these indices, data gaps due to clouds are a problem, as for all optical satellite data products. In contrast 
to that, discrete time series can be obtained using parameters derived from SAR data. As described in Section 3.3.3, several studies already investigated the performance of radar-based parameters, mainly backscatter amplitude, interferometric coherence and polarimetry-based decomposition parameters mostly for mowing event detection $[155,156,158,172]$. Especially the temporal coherence seems to be able to detect mowing events successfully $[154,158]$. However, its performance on larger scales, including a heterogeneous set of grasslands, still needs to be investigated. Apart from that, a combined use of optical and SAR data, for example by fusing Sentinel-1 and -2, will probably improve the analysis of grassland management [193-195].

\subsubsection{Detection of Grazing and Grazing Patterns with Remote Sensing Data}

Grazing is the most frequent management type of grassland globally. Many studies use vegetation indices, biomass or productivity estimations to investigate grazing patterns (for example $[85,167,169,196,197])$. Robinson et al. [24] modeled the global distribution of livestock (cattle, pigs, chicken, ducks) based on polygon statistics and predictor variables including remote sensing data. However, temporal as well as higher spatial resolution grazing intensity information is needed for grassland management to enable degradation mitigation and successful conservation. Another major obstacle in grazing intensity analysis is that the effects from grazing or overgrazing cannot be easily disentangled from climate effects. Conducting multivariate analysis to gain knowledge on the variable importance, e.g., [115], or intensive tests in the field, might support separating these influencing factors. To guarantee successful conservation mechanisms both, climate factors as well as management should be taken into account, as they strongly interrelate [33].

\subsubsection{Grassland Mowing Detection with Remote Sensing Data}

The detection of grassland mowing dates and frequencies plays a central role in Europe. Within European grasslands, a high variability of mowing dynamics exists, as managed grasslands are mown between one to six times per year. All of the reviewed studies analyzing satellite-based mowing detection investigated grassland sites in Europe. For homogeneously managed grasslands (e.g., all monitored grasslands are cut three times per year), satellite data based mowing detection led to satisfactory results $[132,160]$. When grasslands ranging from extensive to intensive management are included in the analyses, the percentage of valid mowing event detections is lower. It was shown that particularly single mowing events on extensively used grasslands are less successfully detected and that the detection of the fourth to sixth mowing event on intensive grasslands is reduced [162]. Furthermore, the validation of mowing date and frequency detection in grasslands is a critical point, as independent validation datasets are often missing, or the validation datasets lack a sufficient temporal and spatial resolution. Validation data for mowing events are acquired on the basis of visual satellite image interpretation, by regular field site visits where mowing events are roughly estimated or there is information on the management from farmers available. Higher resolution (e.g., daily) information on mowing activities would not only improve the validation but could also optimize the detection algorithm. Furthermore, the validation method of detected mowing events using classification approaches is an important point, which is usually based on the confusion matrix of the classification. When grasslands are classified into the two classes 'cut' and 'uncut,' the overall accuracy might be biased, as the 'uncut' class is much larger, and the successful detection of uncut grassland is not the main interest. Focusing on the recall (proportion of identified true positives) or using the more sophisticated F-score would improve the evaluation when the aim is the successful detection of mowing events. Apart from including heterogeneously managed grassland sites and the availability of independent validation data on larger scales, there were also other difficulties in satellite-based mowing detection revealed by the reviewed studies. On the one hand, small parcel sizes are problematic as edge effects are enlarged. On the other hand, piecewise mowing of grassland sites is a major difficulty, as the signals are blurred when analyses are conducted on parcel level. 


\subsubsection{Remote Sensing-Based Detection and Investigation of Grassland Irrigation and Fertilization}

Looking at specific management strategies, it appears that the detection of irrigated grassland and fertilization activity is underrepresented in the field of satellite remote sensing. The role of grassland irrigation probably increases due to climate change. Patterns and effects of irrigation should be investigated as more extreme weather with erratic precipitation events and drought periods can be expected in many grassland areas globally [198]. There were already some attempts made to explore the detection of irrigation or soil moisture of grasslands using satellite data [143,199]. Using Sentinel-1 and Sentinel-2 data might improve the research in this field. Fertilization plays a major role for the nitrogen cycle in grassland ecosystems and the nitrogen status of crop plants is interesting for farmers. The detection of fertilization and/or nitrogen status of plants, however, seems to be more feasible using airborne or handheld remote sensing techniques and mainly considering hyperspectral data, at the moment [200,201].

\section{Conclusions}

The review and assessment of research in the field of satellite data-based analyses of grassland production traits, management and use intensity revealed the following patterns and research opportunities:

- In total, 253 research articles were reviewed, which resulted in a current and comprehensive overview of remote sensing of grassland production traits and management studies.

- Studies on grassland production and management with remote sensing data have increased irregularly, but strongly for the last 20 years.

- The frequency of studies of grassland production and management is globally unequally distributed, where South American (5\% of all studies) and African (4\% of all studies) grasslands seem to be underrepresented. Therefore, there are still large grassland areas which should be further investigated, especially as many people in these countries probably strongly depend on livestock production on grasslands.

- There is a relatively small amount of studies (30\%) on remote sensing of grassland production in Europe, probably due to the large management activities and consequential high variability within grassland production. Research towards detection of management strategies and events and the grassland production on these small and heterogeneously used grassland parcels are needed for successful yield estimations.

- In total, there were only six studies covering the entire globe for their analysis, and apart from LUE-model-based grassland productivity analyses, most studies took place locally. Extending the study area for investigating grassland production and management and including heterogenous grasslands while-at the same time-accounting for the variability among these is an interesting future research focus.

- Time series have always played a central role in grassland production and management analyses, whereby the Landsat and MODIS satellite fleets were in the focus. In the future, the Sentinel fleets and a combination of optical and SAR satellite data will be of high importance.

- Optical satellite data is used in $92 \%$ of research, in particular in research articles focusing on grassland production. For both grassland production and management related studies, only a few combined optical and SAR systems (4\%).

- Quantitative grassland production estimations, such as biomass products, based on remote sensing data would improve from adding temporal information to the results. Especially in highly managed areas, this would facilitate yield estimations. It could also be better to improve process-based models to retrieve biomass information or to apply more advanced machine learning algorithms for an empirical relationship-based biomass analysis. 
- While at the moment, within grassland production analyses, the focus lies on the influence of climate, research would improve from including spatially explicit management information into the analyses.

- Grassland management and use intensity studies based on satellite data are often conducted on a relatively small scale $\left(90 \%\right.$ of studies under $\left.10,000 \mathrm{~km}^{2}\right)$ or focus on only one intensity level or homogeneous grassland. Enlarging the study areas and incorporating diverse grasslands to better account for real conditions would be a valuable direction for future studies in this context.

- More automatized and large-scale grassland products are needed and will enable a continuous monitoring of grasslands worldwide. Thus, knowledge of the state, production and management of grasslands and the influence of climate (change) would be generated and allow for adapted management and conservation plans.

Remote sensing of grassland production traits and management has gained more and more interest recently. This review shows that there are still multiple advancements necessary in this field for future research.

Supplementary Materials: The following are available online at http://www.mdpi.com/2072-4292/12/12/1949/s1, Table S1: Copyright information of images of various grasslands, Table S2: Full list of reviewed research studies.

Author Contributions: Conceptualization, S.R., S.A. and C.K.; Methodology, S.R.; Formal Analysis, S.R.; Investigation, S.R.; Writing-Original Draft Preparation, S.R.; Writing-Review and Editing, S.R., S.A. and C.K.; Visualization, S.R.; Supervision, S.A. and C.K.; Funding Acquisition, S.A. All authors have read and agreed to the published version of the manuscript.

Funding: This research was conducted within the SUSALPS project (https://www.susalps.de/) funded by the German Federal Ministry for Education and Research (BMBF), grant number 031B0516F.

Acknowledgments: We would like to thank the NASA Socioeconomic Data and Applications Center (SEDAC) and the NOAA National Centers for Environmental Information for openly providing global land cover maps and meteorological station data. In addition, we would like to thank the four reviewers for their helpful and constructive comments.

Conflicts of Interest: The authors declare no conflict of interest.

\section{References}

1. Reynolds, S.; Frame, J. Grasslands: Developments, Opportunities, Perspectives; Food \& Agriculture Org.: Rome, Italy, 2005.

2. White, R.; Murray, S.; Rohweder, M. Pilot Analysis of Global Ecosystems—Grassland Ecosystems; World Resources Institute: Washington, DC, USA, 2000.

3. Gibson, D.J. Grasses and Grassland Ecology; Oxford University Press: Oxford, UK, 2009.

4. FAO. The State of Food and Agriculture —Livestock in the Balance; Food \& Agriculture Org.: Rome, Italy, 2009.

5. Hatfield, R.; Davies, J. Global Review of the Economics of Pastoralism; Internatonal Union for Conservation of Nature-IUCN: Gland, Switzerland, 2006.

6. Angelsen, A.; Jagger, P.; Babigumira, R.; Belcher, B.; Hogarth, N.J.; Bauch, S.; Börner, J.; Smith-Hall, C.; Wunder, S. Environmental income and rural livelihoods: A global-comparative analysis. World Dev. 2014, 64, 12-28. [CrossRef] [PubMed]

7. Gibon, A. Managing grassland for production, the environment and the landscape. Challenges at the farm and the landscape level. Livest. Prod. Sci. 2005, 96, 11-31. [CrossRef]

8. Conant, R.T. Challenges and Opportunities for Carbon Sequestration in Grassland Systems-A Technical Report on Grassland Management and Climate Change Mitigation; Food \& Agriculture Org.: Rome, Italy, 2010.

9. Dass, P.; Houlton, B.Z.; Wang, Y.; Warlind, D. Grasslands may be more reliable carbon sinks than forests in California. Environ. Res. Lett. 2018, 13, 074027. [CrossRef]

10. Baer, S.; Kitchen, D.; Blair, J.; Rice, C. Changes in ecosystem structure and function along a chronosequence of restored grasslands. Ecol. Appl. 2002, 12, 1688-1701. [CrossRef]

11. Xiaojun, N.; Xiaodan, W.; Suzhen, L.; Shixian, G.; Haijun, L. 137Cs tracing dynamics of soil erosion, organic carbon and nitrogen in sloping farmland converted from original grassland in Tibetan plateau. Appl. Radiat. Isot. 2010, 68, 1650-1655. [CrossRef] 
12. Reichstein, M.; Ciais, P.; Papale, D.; Valentini, R.; Running, S.; Viovy, N.; Cramer, W.; Granier, A.; Ogee, J.; Allard, V.; et al. Reduction of ecosystem productivity and respiration during the European summer 2003 climate anomaly: A joint flux tower, remote sensing and modelling analysis. Glob. Chang. Biol. 2007, 13, 634-651. [CrossRef]

13. Hilpold, A.; Seeber, J.; Fontana, V.; Niedrist, G.; Rief, A.; Steinwandter, M.; Tasser, E.; Tappeiner, U. Decline of rare and specialist species across multiple taxonomic groups after grassland intensification and abandonment. Biodivers. Conserv. 2018, 27, 3729-3744. [CrossRef]

14. Di Giulio, M.; Edwards, P.J.; Meister, E. Enhancing insect diversity in agricultural grasslands: The roles of management and landscape structure. J. Appl. Ecol. 2001, 38, 310-319. [CrossRef]

15. Lengyel, S.; Déri, E.; Magura, T. Species richness responses to structural or compositional habitat diversity between and within grassland patches: A multi-taxon approach. PLoS ONE 2016, 11, e0149662. [CrossRef]

16. Dixon, A.; Faber-Langendoen, D.; Josse, C.; Morrison, J.; Loucks, C. Distribution mapping of world grassland types. J. Biogeogr. 2014, 41, 2003-2019. [CrossRef]

17. Faber-Langendoen, D.; Josse, C. World Grasslands and Biodiversity Patterns: A Report to IUCN Ecosystem Management Programme; NatureServe: Arlington County, VA, USA, 2010.

18. Allaby, M. A dictionary of Plant Sciences; Oxford University Press: Oxford, UK, 2012.

19. Suttie, J.M.; Reynolds, S.G.; Batello, C. Grasslands of the World; Food \& Agriculture Org.: Rome, Italy, 2005.

20. Allen, V.G.; Batello, C.; Berretta, E.; Hodgson, J.; Kothmann, M.; Li, X.; McIvor, J.; Milne, J.; Morris, C.; Peeters, A.; et al. An international terminology for grazing lands and grazing animals. Grass Forage Sci. 2011, 66, 2-28. [CrossRef]

21. Ramankutty, N.; Evan, A.T.; Monfreda, C.; Foley, J.A. Farming the planet: 1. Geographic distribution of global agricultural lands in the year 2000. Glob. Biogeochem. Cycles 2008, 22, GB1003. [CrossRef]

22. Ramankutty, N.A.T.; Evan, C.; Monfreda, C.; Foley, J.A. Global Agricultural Lands: Pastures, 2000, NY: NASA Socioeconomic Data and Applications Center (SEDAC). Available online: https://doi.org/10.7927/H47H1GGR (accessed on 7 May 2020).

23. NOAA. National Centers for Environmental Information-Global Historical Climatology Network Monthly; NOAA National Centers for Environmental Information: Asheville, NC, USA, 2011.

24. Robinson, T.P.; Wint, G.W.; Conchedda, G.; Van Boeckel, T.P.; Ercoli, V.; Palamara, E.; Cinardi, G.; D'Aietti, L.; Hay, S.I.; Gilbert, M. Mapping the global distribution of livestock. PLoS ONE 2014, 9, e96084. [CrossRef] [PubMed]

25. Chi, D.; Wang, H.; Li, X.; Liu, H.; Li, X. Assessing the effects of grazing on variations of vegetation NPP in the Xilingol Grassland, China, using a grazing pressure index. Ecol. Indic. 2018, 88, 372-383. [CrossRef]

26. Thenkabail, P.S.; Biradar, C.M.; Noojipady, P.; Dheeravath, V.; Li, Y.; Velpuri, M.; Gumma, M.; Gangalakunta, O.R.P.; Turral, H.; Cai, X.; et al. Global irrigated area map (GIAM), derived from remote sensing, for the end of the last millennium. Int. J. Remote Sens. 2009, 30, 3679-3733. [CrossRef]

27. Dlamini, P.; Chivenge, P.; Chaplot, V. Overgrazing decreases soil organic carbon stocks the most under dry climates and low soil pH: A meta-analysis shows. Agric. Ecosyst. Environ. 2016, 221, 258-269. [CrossRef]

28. Han, G.; Hao, X.; Zhao, M.; Wang, M.; Ellert, B.H.; Willms, W.; Wang, M. Effect of grazing intensity on carbon and nitrogen in soil and vegetation in a meadow steppe in Inner Mongolia. Agric. Ecosyst. Environ. 2008, 125, 21-32. [CrossRef]

29. Butterbach-Bahl, K.; Gundersen, P.; Ambus, P.; Augustin, J.; Beier, C.; Boeckx, P.; Dannenmann, M.; Sanchez Gimeno, B.; Ibrom, A.; Kiese, R.; et al. Nitrogen processes in terrestrial ecosystems. In The European Nitrogen Assessment: Sources, Effects and Policy Perspectives; Cambridge University Press: Cambridge, UK, 2011; pp. 99-125.

30. Jarvis, S.; Hutchings, N.J.; Brentrup, F.; Olesen, J.E.; van der Hoek, K.W. Nitrogen flows in farming systems across Europe. In European Nitrogen Assessment; Cambridge University Press: Cambridge, UK, 2011; pp. 211-228.

31. Vries, F.T.; de Bloem, J.; Quirk, H.; Stevens, C.J.; Bol, R.; Bardgett, R.D. Extensive management promotes plant and microbial nitrogen retention in temperate grassland. PLoS ONE 2012, 7, e51201. [CrossRef]

32. Müller, I.B.; Buhk, C.; Lange, D.; Entling, M.H.; Schirmel, J. Contrasting effects of irrigation and fertilization on plant diversity in hay meadows. Basic Appl. Ecol. 2016, 17, 576-585. [CrossRef] 
33. Bernhardt-Römermann, M.; Römermann, C.; Sperlich, S.; Schmidt, W. Explaining grassland biomass-the contribution of climate, species and functional diversity depends on fertilization and mowing frequency. J. Appl. Ecol. 2011, 48, 1088-1097. [CrossRef]

34. Moinet, G.Y.K.; Cieraad, E.; Turnbull, M.H.; Whitehead, D. Effects of irrigation and addition of nitrogen fertiliser on net ecosystem carbon balance for a grassland. Sci. Total Environ. 2017, 579, 1715-1725. [CrossRef] [PubMed]

35. Kuemmerle, T.; Erb, K.; Meyfroidt, P.; Müller, D.; Verburg, P.H.; Estel, S.; Haberl, H.; Hostert, P.; Jepsen, M.R.; Kastner, T.; et al. Challenges and opportunities in mapping land use intensity globally. Curr. Opin. Environ. Sustain. 2013, 5, 484-493. [CrossRef]

36. Chen, H.; Shao, L.; Zhao, M.; Zhang, X.; Zhang, D. Grassland conservation programs, vegetation rehabilitation and spatial dependency in Inner Mongolia, China. Land Use Policy 2017, 64, 429-439. [CrossRef]

37. Cojocariu, L.; Horablaga, M.; Marian, F.; Bostan, C.; Mazăre, V.; Stroia, M.S. Implementation of the ecological European network Natura 2000 in the area of grasslands and hayfields. Res. J. Agric. Sci. 2010, 42, 398-404.

38. Leisher, C.; Hess, S.; Boucher, T.M.; Beukering, P.; van Sanjayan, M. Measuring the impacts of community-based grasslands management in Mongolia's Gobi. PLoS ONE 2012, 7, e30991. [CrossRef]

39. Wu, W.; De Pauw, E.; Zucca, C. Using remote sensing to assess impacts of land management policies in the Ordos rangelands in China. Int. J. Digit. Earth 2013, 6, 81-102. [CrossRef]

40. European Commission (EU) Regulation No 1305/2013 of the European Parliament and of the Council of 17 December 2013 on support for rural development by the European Agricultural Fund for Rural Development (EAFRD) and repealing Council Regulation (EC) No 1698/2005. OJ L (Off. J. Eur.n Union L 347/487) 2013, 347, 487-548.

41. Nestola, E.; Calfapietra, C.; Emmerton, C.A.; Wong, C.; Thayer, D.R.; Gamon, J.A. Monitoring grassland seasonal carbon dynamics, by integrating MODIS NDVI, proximal optical sampling, and eddy covariance measurements. Remote Sens. 2016, 8, 260. [CrossRef]

42. Atzberger, C. Advances in remote sensing of agriculture: Context description, existing operational monitoring systems and major information needs. Remote Sens. 2013, 5, 949-981. [CrossRef]

43. Rast, M.; Painter, T.H. Earth Observation Imaging Spectroscopy for Terrestrial Systems: An Overview of Its History, Techniques, and Applications of Its Missions. Surv. Geophys. 2019, 40, 303-331. [CrossRef]

44. Transon, J.; d'Andrimont, R.; Maugnard, A.; Defourny, P. Survey of hyperspectral earth observation applications from space in the sentinel-2 context. Remote Sens. 2018, 10, 157. [CrossRef]

45. Verrelst, J.; Malenovsk, Z.; Van der Tol, C.; Camps-Valls, G.; Gastellu-Etchegorry, J.-P.; Lewis, P.; North, P.; Moreno, J. Quantifying vegetation biophysical variables from imaging spectroscopy data: A review on retrieval methods. Surv. Geophys. 2019, 40, 589-629. [CrossRef]

46. Hill, M.J.; Donald, G.E.; Vickery, P.J. Relating radar backscatter to biophysical properties of temperate perennial grassland. Remote Sens. Environ. 1999, 67, 15-31. [CrossRef]

47. Wegmuller, U.; Werner, C. Retrieval of vegetation parameters with SAR interferometry. IEEE Trans. Geosci. Remote Sens. 1997, 35, 18-24. [CrossRef]

48. McNairn, H.; Brisco, B. The application of C-band polarimetric SAR for agriculture: A review. Can. J. Remote Sens. 2004, 30, 525-542. [CrossRef]

49. McNairn, H.; Shang, J. A review of multitemporal synthetic aperture radar (SAR) for crop monitoring. In Multitemporal Remote Sensing; Springer: Cham, Switzerland, 2016; pp. 317-340.

50. Ali, I.; Cawkwell, F.; Dwyer, E.; Barrett, B.; Green, S. Satellite remote sensing of grasslands: From observation to management. J. Plant Ecol. 2016, 9, 649-671. [CrossRef]

51. Hill, M.J. Grazing agriculture-managed pasture, grassland and rangeland. In Manual of Remote Sensing, Remote Sensing for Natural Resource Management and Environmental Monitoring; Ustin, S.L., Ed.; Wiley International: New York, NY, USA, 2004; Volume 4, p. 768.

52. Lu, D. The potential and challenge of remote sensing-based biomass estimation. Int. J. Remote Sens. 2006, 27, 1297-1328. [CrossRef]

53. Schellberg, J.; Hill, M.J.; Gerhards, R.; Rothmund, M.; Braun, M. Precision agriculture on grassland: Applications, perspectives and constraints. Eur. J. Agron. 2008, 29, 59-71. [CrossRef]

54. Shoko, C.; Mutanga, O.; Dube, T. Progress in the remote sensing of C 3 and C4 grass species aboveground biomass over time and space. ISPRS J. Photogramm. Remote Sens. 2016, 120, 13-24. [CrossRef] 
55. Tucker, C.J. A critical review of remote sensing and other methods for non-destructive estimation of standing crop biomass. Grass Forage Sci. 1980, 35, 177-182. [CrossRef]

56. Tueller, P.T. Remote sensing technology for rangeland management applications. Rangel. Ecol. Manag./J. Range Manag. Arch. 1989, 42, 442-453. [CrossRef]

57. Tueller, P. Remote sensing in the management of rangelands. Ann. Arid Zone 1995, 34, 191-207.

58. Wachendorf, M.; Fricke, T.; Möckel, T. Remote sensing as a tool to assess botanical composition, structure, quantity and quality of temperate grasslands. Grass and Forage Sci. 2018, 73, 1-14. [CrossRef]

59. Franklin, K.; Molina-Freaner, F. Consequences of Buffelgrass Pasture Development for Primary Productivity, Perennial Plant Richness, and Vegetation Structure in the Drylands of Sonora, Mexico. Conserv. Biol. 2010, 24, 1664-1673. [CrossRef]

60. Gao, Q.; Schwartz, M.W.; Zhu, W.; Wan, Y.; Qin, X.; Ma, X.; Liu, S.; Williamson, M.A.; Peters, C.B.; Li, Y. Changes in Global Grassland Productivity during 1982 to 2011 Attributable to Climatic Factors. Remote Sens. 2016, 8, 384. [CrossRef]

61. Gu, Y.; Wylie, B.K. Developing a 30-m grassland productivity estimation map for central Nebraska using 250-m MODIS and 30-m Landsat-8 observations. Remote Sens. Environ. 2015, 171, 291-298. [CrossRef]

62. Kath, J.; Brocque, A.F.L.; Reardon-Smith, K.; Apan, A. Remotely sensed agricultural grassland productivity responses to land use and hydro-climatic drivers under extreme drought and rainfall. Agric. For. Meteorol. 2019, 268, 11-22. [CrossRef]

63. Qamer, F.M.; Xi, C.; Abbas, S.; Murthy, M.S.; Ning, W.; Anming, B. An assessment of productivity patterns of grass-dominated Rangelands in the Hindu Kush Karakoram Region, Pakistan. Sustainability 2016, 8, 961. [CrossRef]

64. Reeves, M.C.; Baggett, L.S. A remote sensing protocol for identifying rangelands with degraded productive capacity. Ecol. Indic. 2014, 43, 172-182. [CrossRef]

65. Ricotta, C.; Reed, B.C.; Tieszen, L.T. The role of C3 and C4 grasses to interannual variability in remotely sensed ecosystem performance over the US Great Plains. Int. J. Remote Sens. 2003, 24, 4421-4431. [CrossRef]

66. Tucker, C.J.; Justice, C.; Prince, S. Monitoring the grasslands of the Sahel 1984-1985. Int. J. Remote Sens. 1986, 7, 1571-1581. [CrossRef]

67. Yang, L.; Wylie, B.K.; Tieszen, L.L.; Reed, B.C. An analysis of relationships among climate forcing and time-integrated NDVI of grasslands over the US northern and central Great Plains. Remote Sens. Environ. 1998, 65, 25-37. [CrossRef]

68. Yin, F.; Deng, X.; Jin, Q.; Yuan, Y.; Zhao, C. The impacts of climate change and human activities on grassland productivity in Qinghai Province, China. Front. Earth Sci. 2014, 8, 93-103. [CrossRef]

69. Zhou, Y.; Zhang, L.; Xiao, J.; Chen, S.; Kato, T.; Zhou, G. A Comparison of Satellite-Derived Vegetation Indices for Approximating Gross Primary Productivity of Grasslands. Rangel. Ecol. Manag. 2014, 67, 9-18. [CrossRef]

70. Yan, D.; Scott, R.; Moore, D.; Biederman, J.; Smith, W. Understanding the relationship between vegetation greenness and productivity across dryland ecosystems through the integration of PhenoCam, satellite, and eddy covariance data. Remote Sens. Environ. 2019, 223, 50-62. [CrossRef]

71. Wylie, B.; Howard, D.; Dahal, D.; Gilmanov, T.; Ji, L.; Zhang, L.; Smith, K. Grassland and Cropland Net Ecosystem Production of the US Great Plains: Regression Tree Model Development and Comparative Analysis. Remote Sens. 2016, 8, 944. [CrossRef]

72. Edirisinghe, A.; Hill, M.J.; Donald, G.E.; Hyder, M. Quantitative mapping of pasture biomass using satellite imagery. Int. J. Remote Sens. 2011, 32, 2699-2724. [CrossRef]

73. Edirisinghe, A.; Clark, D.; Waugh, D. Spatio-temporal modelling of biomass of intensively grazed perennial dairy pastures using multispectral remote sensing. Int. J. Appl. Earth Obs. Geoinf. 2012, 16, 5-16. [CrossRef]

74. Smith, R.C.; Adams, M.; Gittins, S.; Gherardi, S.; Wood, D.; Maier, S.; Stovold, R.; Donald, G.; Khohkar, S.; Allen, A. Near real-time Feed On Offer (FOO) from MODIS for early season grazing management of Mediterranean annual pastures. Int. J. Remote Sens. 2011, 32, 4445-4460. [CrossRef]

75. Magiera, A.; Feilhauer, H.; Waldhardt, R.; Wiesmair, M.; Otte, A. Modelling biomass of mountainous grasslands by including a species composition map. Ecol. Indic. 2017, 78, 8-18. [CrossRef]

76. Ramoelo, A.; Cho, M.A.; Mathieu, R.; Madonsela, S.; van de Kerchove, R.; Kaszta, Z.; Wolff, E. Monitoring grass nutrients and biomass as indicators of rangeland quality and quantity using random forest modelling and WorldView-2 data. Int. J. Appl. Earth Obs. Geoinf. 2015, 43, 43-54. [CrossRef] 
77. Wang, Y.; Wu, G.; Deng, L.; Tang, Z.; Wang, K.; Sun, W.; Shangguan, Z. Prediction of aboveground grassland biomass on the Loess Plateau, China, using a random forest algorithm. Sci. Rep. 2017, 7, 6940. [CrossRef] [PubMed]

78. Zeng, N.; Ren, X.; He, H.; Zhang, L.; Zhao, D.; Ge, R.; Li, P.; Niu, Z. Estimating grassland aboveground biomass on the Tibetan Plateau using a random forest algorithm. Ecol. Indic. 2019, 102, 479-487. [CrossRef]

79. Zhang, B.; Zhang, L.; Xie, D.; Yin, X.; Liu, C.; Liu, G. Application of Synthetic NDVI Time Series Blended from Landsat and MODIS Data for Grassland Biomass Estimation. Remote Sens. 2016, 8, 10. [CrossRef]

80. Baghi, N.G.; Oldeland, J. Do soil-adjusted or standard vegetation indices better predict above ground biomass of semi-arid, saline rangelands in North-East Iran? Int. J. Remote Sens. 2019, 40, 8223-8235. [CrossRef]

81. Yin, G.; Li, A.; Wu, C.; Wang, J.; Xie, Q.; Zhang, Z.; Nan, X.; Jin, H.; Bian, J.; Lei, G. Seamless Upscaling of the Field-Measured Grassland Aboveground Biomass Based on Gaussian Process Regression and Gap-Filled Landsat 8 OLI Reflectance. ISPRS Int. J. Geo-Inf. 2018, 7, 242. [CrossRef]

82. Ali, I.; Cawkwell, F.; Green, S.; Dwyer, N. Application of statistical and machine learning models for grassland yield estimation based on a hypertemporal satellite remote sensing time series. In Proceedings of the 2014 IEEE Geoscience and Remote Sensing Symposium, Quebec City, QC, Canada, 13-18 July 2014; pp. 5060-5063.

83. Ali, I.; Cawkwell, F.; Dwyer, E.; Green, S. Modeling Managed Grassland Biomass Estimation by Using Multitemporal Remote Sensing Data-A Machine Learning Approach. IEEE J. Sel. Top. Appl. Earth Obs. Remote Sens. 2017, 10, 3254-3264. [CrossRef]

84. Li, F.; Jiang, L.; Wang, X.; Zhang, X.; Zheng, J.; Zhao, Q. Estimating grassland aboveground biomass using multitemporal MODIS data in the West Songnen Plain, China. J. Appl. Remote Sens. 2013, 7, 073546. [CrossRef]

85. Li, F.; Zheng, J.; Wang, H.; Luo, J.; Zhao, Y.; Zhao, R. Mapping grazing intensity using remote sensing in the Xilingol steppe region, Inner Mongolia, China. Remote Sens. Lett. 2016, 7, 328-337. [CrossRef]

86. Quan, X.; He, B.; Yebra, M.; Yin, C.; Liao, Z.; Zhang, X.; Li, X. A radiative transfer model-based method for the estimation of grassland aboveground biomass. Int. J. Appl. Earth Obs. Geoinf. 2017, 54, 159-168. [CrossRef]

87. Xie, Y.; Sha, Z.; Yu, M.; Bai, Y.; Zhang, L. A comparison of two models with Landsat data for estimating above ground grassland biomass in Inner Mongolia, China. Ecol. Model. 2009, 220, 1810-1818. [CrossRef]

88. Yang, S.; Feng, Q.; Liang, T.; Liu, B.; Zhang, W.; Xie, H. Modeling grassland above-ground biomass based on artificial neural network and remote sensing in the Three-River Headwaters Region. Remote Sens. Environ. 2018, 204, 448-455. [CrossRef]

89. Marsett, R.C.; Qi, J.; Heilman, P.; Biedenbender, S.H.; Watson, M.C.; Amer, S.; Weltz, M.; Goodrich, D.; Marsett, R. Remote sensing for grassland management in the arid southwest. Rangel. Ecol. Manag. 2006, 59, 530-540. [CrossRef]

90. Wehlage, D.C.; Gamon, J.A.; Thayer, D.; Hildebrand, D.V. Interannual Variability in Dry Mixed-Grass Prairie Yield: A Comparison of MODIS, SPOT, and Field Measurements. Remote Sens. 2016, 8, 872. [CrossRef]

91. Jacquemoud, S.; Verhoef, W.; Baret, F.; Bacour, C.; Zarco-Tejada, P.J.; Asner, G.P.; François, C.; Ustin, S.L. PROSPECT+ SAIL models: A review of use for vegetation characterization. Remote Sens. Environ. 2009, 113, S56-S66. [CrossRef]

92. Bella, D.; Faivre, R.; Ruget, F.; Seguin, B.; Guerif, M.; Combal, B.; Weiss, M.; Rebella, C. Remote sensing capabilities to estimate pasture production in France. Int. J. Remote Sens. 2004, 25, 5359-5372. [CrossRef]

93. Donald, G.; Gherardi, S.; Edirisinghe, A.; Gittins, S.; Henry, D.; Mata, G. Using MODIS imagery, climate and soil data to estimate pasture growth rates on farms in the south-west of Western Australia. Anim. Prod. Sci. 2010, 50, 611-615. [CrossRef]

94. Hill, M.J.; Donald, G.E.; Hyder, M.W.; Smith, R.C. Estimation of pasture growth rate in the south west of Western Australia from AVHRR NDVI and climate data. Remote Sens. Environ. 2004, 93, 528-545. [CrossRef]

95. Monteith, J. Solar radiation and productivity in tropical ecosystems. J. Appl. Ecol. 1972, 9, 747-766. [CrossRef]

96. Monteith, J.L. Climate and the efficiency of crop production in Britain. Philos. Trans. R. Soc. Lond. B Biol. Sci. 1977, 281, 277-294.

97. Sun, B.; Li, Z.; Gao, Z.; Guo, Z.; Wang, B.; Hu, X.; Bai, L. Grassland degradation and restoration monitoring and driving forces analysis based on long time-series remote sensing data in Xilin Gol League. Acta Ecol. Sin. 2017, 37, 219-228. [CrossRef] 
98. Zhang, Y.; Qi, W.; Zhou, C.; Ding, M.; Liu, L.; Gao, J.; Bai, W.; Wang, Z.; Zheng, D. Spatial and temporal variability in the net primary production of alpine grassland on the Tibetan Plateau since 1982. J. Geogr. Sci. 2014, 24, 269-287. [CrossRef]

99. Potter, C.S.; Randerson, J.T.; Field, C.B.; Matson, P.A.; Vitousek, P.M.; Mooney, H.A.; Klooster, S.A. Terrestrial ecosystem production: A process model based on global satellite and surface data. Glob. Biogeochem. Cycles 1993, 7, 811-841. [CrossRef]

100. Yu, R.; Evans, A.J.; Malleson, N. Quantifying grazing patterns using a new growth function based on MODIS Leaf Area Index. Remote Sens. Environ. 2018, 209, 181-194. [CrossRef]

101. Xiao, X.; Zhang, Q.; Braswell, B.; Urbanski, S.; Boles, S.; Wofsy, S.; Moore III, B.; Ojima, D. Modeling gross primary production of temperate deciduous broadleaf forest using satellite images and climate data. Remote Sens. Environ. 2004, 91, 256-270. [CrossRef]

102. You, Y.; Wang, S.; Ma, Y.; Wang, X.; Liu, W. Improved Modeling of Gross Primary Productivity of Alpine Grasslands on the Tibetan Plateau Using the Biome-BGC Model. Remote Sens. 2019, 11, 1287. [CrossRef]

103. Maselli, F.; Argenti, G.; Chiesi, M.; Angeli, L.; Papale, D. Simulation of grassland productivity by the combination of ground and satellite data. Agric. Ecosyst. Environ. 2013, 165, 163-172. [CrossRef]

104. Wang, J.; Li, A.; Bian, J. Simulation of the Grazing Effects on Grassland Aboveground Net Primary Production Using DNDC Model Combined with Time-Series Remote Sensing Data-A Case Study in Zoige Plateau, China. Remote Sens. 2016, 8, 168. [CrossRef]

105. Fan, J.-W.; Shao, Q.-Q.; Liu, J.-Y.; Wang, J.-B.; Harris, W.; Chen, Z.-Q.; Zhong, H.-P.; Xu, X.-L.; Liu, R.-G. Assessment of effects of climate change and grazing activity on grassland yield in the Three Rivers Headwaters Region of Qinghai-Tibet Plateau, China. Environ. Monit. Assess. 2010, 170, 571-584. [CrossRef]

106. Jia, W.; Liu, M.; Wang, D.; He, H.; Shi, P.; Li, Y.; Wang, Y. Uncertainty in simulating regional gross primary productivity from satellite based models over northern China grassland. Ecol. Indic. 2018, 88, 134-143. [CrossRef]

107. Tan, K.; Ciais, P.; Piao, S.; Wu, X.; Tang, Y.; Vuichard, N.; Liang, S.; Fang, J. Application of the ORCHIDEE global vegetation model to evaluate biomass and soil carbon stocks of Qinghai-Tibetan grasslands. Glob. Biogeochem. Cycles 2010, 24. [CrossRef]

108. He, H.; Liu, M.; Xiao, X.; Ren, X.; Zhang, L.; Sun, X.; Yang, Y.; Li, Y.; Zhao, L.; Shi, P.; et al. Large-scale estimation and uncertainty analysis of gross primary production in Tibetan alpine grasslands. J. Geophys. Res. Biogeosci. 2014, 119, 466-486. [CrossRef]

109. Rossini, M.; Cogliati, S.; Meroni, M.; Migliavacca, M.; Galvagno, M.; Busetto, L.; Cremonese, E.; Julitta, T.; Siniscalco, C.; Morra di Cella, U.; et al. Remote sensing-based estimation of gross primary production in a subalpine grassland. Biogeosciences 2012, 9, 2565-2584. [CrossRef]

110. Wang, Z.; Xiao, X.; Yan, X. Modeling gross primary production of maize cropland and degraded grassland in northeastern China. Agric. For. Meteorol. 2010, 150, 1160-1167. [CrossRef]

111. Wu, W.X.; Wang, S.Q.; Xio, X.M.; Yu, G.R.; Fu, Y.L.; Hao, Y.B. Modeling gross primary production of a temperate grassland ecosystem in Inner Mongolia, China, using MODIS imagery and climate data. Sci. China Ser. D Earth Sci. 2008, 51, 1501-1512. [CrossRef]

112. Zhou, Y.; Xiao, X.; Wagle, P.; Bajgain, R.; Mahan, H.; Basara, J.B.; Dong, J.; Qin, Y.; Zhang, G.; Luo, Y.; et al. Examining the short-term impacts of diverse management practices on plant phenology and carbon fluxes of Old World bluestems pasture. Agric. For. Meteorol. 2017, 237, 60-70. [CrossRef]

113. Gao, T.; Xu, B.; Yang, X.; Deng, S.; Liu, Y.; Jin, Y.; Ma, H.; Li, J.; Yu, H.; Zheng, X.; et al. Aboveground net primary productivity of vegetation along a climate-related gradient in a Eurasian temperate grassland: Spatiotemporal patterns and their relationships with climate factors. Environ. Earth Sci. 2017, 76, 56. [CrossRef]

114. Jia, X.; Xie, B.; Shao, M.; Zhao, C. Primary Productivity and Precipitation-Use Efficiency in Temperate Grassland in the Loess Plateau of China. PLoS ONE 2015, 10, e0135490. [CrossRef]

115. Li, Z.; Huffman, T.; McConkey, B.; Townley-Smith, L. Monitoring and modeling spatial and temporal patterns of grassland dynamics using time-series MODIS NDVI with climate and stocking data. Remote Sens. Environ. 2013, 138, 232-244. [CrossRef]

116. Zhao, F.; Xu, B.; Yang, X.; Xia, L.; Jin, Y.; Li, J.; Zhang, W.; Guo, J.; Shen, G. Modelling and analysis of net primary productivity and its response mechanism to climate factors in temperate grassland, northern China. Int. J. Remote Sens. 2019, 40, 2259-2277. [CrossRef] 
117. Petrie, M.D.; Brunsell, N.A.; Vargas, R.; Collins, S.; Flanagan, L.B.; Hanan, N.; Litvak, M.E.; Suyker, A.E. The sensitivity of carbon exchanges in Great Plains grasslands to precipitation variability. J. Geophys. Res. Biogeosci. 2016, 121, 280-294. [CrossRef]

118. Mao, D.; Wang, Z.; Li, L.; Ma, W. Spatiotemporal dynamics of grassland aboveground net primary productivity and its association with climatic pattern and changes in Northern China. Ecol. Indic. 2014, 41, 40-48. [CrossRef]

119. Xiong, Q.; Xiao, Y.; Halmy, M.W.A.; Dakhil, M.A.; Liang, P.; Liu, C.; Zhang, L.; Pandey, B.; Pan, K.; El Kafraway, S.B.; et al. Monitoring the impact of climate change and human activities on grassland vegetation dynamics in the northeastern Qinghai-Tibet Plateau of China during 2000-2015. J. Arid Land 2019, 11, 637-651. [CrossRef]

120. Wang, R.; Gamon, J.A.; Emmerton, C.A.; Springer, K.R.; Yu, R.; Hmimina, G. Detecting intra-and inter-annual variability in gross primary productivity of a North American grassland using MODIS MAIAC data. Agric. For. Meteorol. 2020, 281, 107859. [CrossRef]

121. Flanagan, L.B.; Adkinson, A.C. Interacting controls on productivity in a northern Great Plains grassland and implications for response to ENSO events. Glob. Chang. Biol. 2011, 17, 3293-3311. [CrossRef]

122. Li, F.; Chen, J.Q.; Zeng, Y.; Wu, B.F.; Zhang, X.Q. Renewed Estimates of Grassland Aboveground Biomass Showing Drought Impacts. J. Geophys. Res. Biogeosci. 2018, 123, 138-148. [CrossRef]

123. Wu, X.; Li, P.; Jiang, C.; Liu, P.; He, J.; Hou, X. Climate changes during the past 31 years and their contribution to the changes in the productivity of rangeland vegetation in the Inner Mongolian typical steppe. Rangel. J. 2014, 36, 519-526. [CrossRef]

124. Dusseux, P.; Gong, X.; Corpetti, T.; Hubert-Moy, L.; Corgne, S. Contribution of radar images for grassland management identification. In Proceedings of the Remote Sensing for Agriculture, Ecosystems, and Hydrology XIV, Edinburgh, UK, 23 October 2012; Volume 8531, pp. 24-30.

125. Dusseux, P.; Corpetti, T.; Hubert-Moy, L. Temporal kernels for the identification of grassland management using time series of high spatial resolution satellite images. In Proceedings of the 2013 IEEE International Geoscience and Remote Sensing Symposium-IGARSS, Melbourne, Australia, 21-26 July 2013; pp. 3258-3260.

126. Price, K.P.; Guo, X.; Stiles, J.M. Comparison of Landsat TM and ERS-2 SAR data for discriminating among grassland types and treatments in eastern Kansas. Comput. Electron. Agric. 2002, 37, 157-171. [CrossRef]

127. Asam, S.; Klein, D.; Dech, S. Estimation of grassland use intensities based on high spatial resolution LAI time series. ISPRS Int. Arch. Photogramm. Remote Sens. Spat. Inf. Sci. 2015, XL-7/W3, 285-291. [CrossRef]

128. Franke, J.; Keuck, V.; Siegert, F. Assessment of grassland use intensity by remote sensing to support conservation schemes. J. Nat. Conserv. 2012, 20, 125-134. [CrossRef]

129. Kurtz, D.B.; Schellberg, J.; Braun, M. Ground and satellite based assessment of rangeland management in sub-tropical Argentina. Appl. Geogr. 2010, 30, 210-220. [CrossRef]

130. Halabuk, A.; Mojses, M.; Halabuk, M.; David, S. Towards Detection of Cutting in Hay Meadows by Using of NDVI and EVI Time Series. Remote Sens. 2015, 7, 6107-6132. [CrossRef]

131. Siegmund, R.; Grant, K.; Wagner, M.; Hartmann, S. Satellite-based monitoring of grassland: Assessment of harvest dates and frequency using SAR. In Proceedings of the Remote Sensing for Agriculture, Ecosystems, and Hydrology XVIII, Proceedings of SPIE, Edinburgh, UK, 26 October 2016; Volume 9998.

132. Taravat, A.; Wagner, M.P.; Oppelt, N. Automatic Grassland Cutting Status Detection in the Context of Spatiotemporal Sentinel-1 Imagery Analysis and Artificial Neural Networks. Remote Sens. 2019, 11, 711. [CrossRef]

133. Barrett, B.; Nitze, I.; Green, S.; Cawkwell, F. Assessment of multi-temporal, multi-sensor radar and ancillary spatial data for grasslands monitoring in Ireland using machine learning approaches. Remote Sens. Environ. 2014, 152, 109-124. [CrossRef]

134. Dusseux, P.; Hubert-Moy, L.; Lecerf, R.; Gong, X.; Corpetti, T. Identification of grazed and mown grasslands using a time series of high-spatial-resolution remote sensing images. In Proceedings of the 6th International Workshop on the Analysis of Multi-temporal Remote Sensing Images (Multi-Temp), Trento, Italy, 12-14 July 2011; pp. 145-148.

135. Siegmund, R.; Redl, S.; Wagner, M.; Hartmann, S. Grassland monitoring based on Sentinel-1. In Proceedings of the Remote Sensing for Agriculture, Ecosystems, and Hydrology XXI, Strasbourg, France, 21 October 2019; Volume 11149, pp. 1-19. 
136. Dusseux, P.; Corpetti, T.; Hubert-Moy, L.; Corgne, S. Combined Use of Multi-Temporal Optical and Radar Satellite Images for Grassland Monitoring. Remote Sens. 2014, 6, 6163-6182. [CrossRef]

137. Lopes, M.; Fauvel, M.; Girard, S.; Sheeren, D. Object-Based Classification of Grasslands from High Resolution Satellite Image Time Series Using Gaussian Mean Map Kernels. Remote Sens. 2017, 9, 688. [CrossRef]

138. Schuster, C.; Schmidt, T.; Conrad, C.; Kleinschmit, B.; Foerster, M. Grassland habitat mapping by intra-annual time series analysis-Comparison of RapidEye and TerraSAR-X satellite data. Int. J. Appl. Earth Obs. Geoinf. 2015, 34, 25-34. [CrossRef]

139. Bekkema, M.E.; Eleveld, M. Mapping Grassland Management Intensity Using Sentinel-2 Satellite Data. GI_Forum 2018 2018, 1, 194-213. [CrossRef]

140. Schuster, C.; Ali, I.; Lohmann, P.; Frick, A.; Foerster, M.; Kleinschmit, B. Towards Detecting Swath Events in TerraSAR-X Time Series to Establish NATURA 2000 Grassland Habitat Swath Management as Monitoring Parameter. Remote Sens. 2011, 3, 1308-1322. [CrossRef]

141. Guo, X.; Price, K.P.; Stiles, J. Grasslands Discriminant Analysis Using Landsat TM Single and Multitemporal Data. Photogramm. Eng. Remote Sens. 2003, 69, 1255-1262. [CrossRef]

142. Guo, X.; Wilmshurst, J.; McCanny, S.; Fargey, P.; Richard, P. Measuring spatial and vertical heterogeneity of grasslands using remote sensing techniques. J. Environ. Inform. 2004, 3, 24-32. [CrossRef]

143. Hajj, M.E.; Baghdadi, N.; Belaud, G.; Zribi, M.; Cheviron, B.; Courault, D.; Hagolle, O.; Charron, F. Irrigated Grassland Monitoring Using a Time Series of TerraSAR-X and COSMO-SkyMed X-Band SAR Data. Remote Sens. 2014, 6, 10002-10032. [CrossRef]

144. John, R.; Chen, J.; Giannico, V.; Park, H.; Xiao, J.; Shirkey, G.; Ouyang, Z.; Shao, C.; Lafortezza, R.; Qi, J. Grassland canopy cover and aboveground biomass in Mongolia and Inner Mongolia: Spatiotemporal estimates and controlling factors. Remote Sens. Environ. 2018, 213, 34-48. [CrossRef]

145. Liu, Y.; Zha, Y.; Gao, J.; Ni, S. Assessment of grassland degradation near Lake Qinghai, West China, using Landsat TM and in situ reflectance spectra data. Int. J. Remote Sens. 2004, 25, 4177-4189. [CrossRef]

146. Numata, I.; Roberts, D.A.; Chadwick, O.A.; Schimel, J.; Sampaio, F.R.; Leonidas, F.C.; Soares, J.V. Characterization of pasture biophysical properties and the impact of grazing intensity using remotely sensed data. Remote Sens. Environ. 2007, 109, 314-327. [CrossRef]

147. Roeder, A.; Udelhoven, T.; Hill, J.; del Barrio, G.; Tsiourlis, G. Trend analysis of Landsat-TM and -ETM+ imagery to monitor grazing impact in a rangeland ecosystem in Northern Greece. Remote Sens. Environ. 2008, 112, 2863-2875. [CrossRef]

148. Wylie, B.; Meyer, D.; Tieszen, L.; Mannel, S. Satellite mapping of surface biophysical parameters at the biome scale over the North American grasslands: A case study. Remote Sens. Environ. 2002, 79, 266-278. [CrossRef]

149. Todd, S.W.; Hoffer, R.M.; Milchunas, D.G. Biomass estimation on grazed and ungrazed rangelands using spectral indices. Int. J. Remote Sens. 1998, 19, 427-438. [CrossRef]

150. Blanco, L.J.; Ferrando, C.A.; Biurrun, F.N. Remote sensing of spatial and temporal vegetation patterns in two grazing systems. Rangel. Ecol. Manag. 2009, 62, 445-451. [CrossRef]

151. Grant, K.; Wagner, M.; Siegmund, R.; Hartmann, S. The use of radar images for detecting when grass is harvested and thereby improve grassland yield estimates. In Proceedings of the Grassland Science in Europe, Grassland Science Federation, Wageningen, The Netherlands, 14-17 June 2015; Volume 20, pp. 419-421.

152. Rossi, M.; Niedrist, G.; Asam, S.; Tonon, G.; Tomelleri, E.; Zebisch, M. A Comparison of the Signal from Diverse Optical Sensors for Monitoring Alpine Grassland Dynamics. Remote Sens. 2019, 11, 296. [CrossRef]

153. Stendardi, L.; Karlsen, S.R.; Niedrist, G.; Gerdol, R.; Zebisch, M.; Rossi, M.; Notarnicola, C. Exploiting Time Series of Sentinel-1 and Sentinel-2 Imagery to Detect Meadow Phenology in Mountain Regions. Remote Sens. 2019, 11, 542. [CrossRef]

154. Tamm, T.; Zalite, K.; Voormansik, K.; Talgre, L. Relating Sentinel-1 interferometric coherence to mowing events on grasslands. Remote Sens. 2016, 8, 802. [CrossRef]

155. Voormansik, K.; Jagdhuber, T.; Olesk, A.; Hajnsek, I.; Papathanassiou, K.P. Towards a detection of grassland cutting practices with dual polarimetric TerraSAR-X data. Int. J. Remote Sens. 2013, 34, 8081-8103. [CrossRef]

156. Voormansik, K.; Jagdhuber, T.; Zalite, K.; Noorma, M.; Hajnsek, I. Observations of cutting practices in agricultural grasslands using polarimetric SAR. IEEE J. Sel. Top. Appl. Earth Obs. Remote Sens. 2015, 9, 1382-1396. [CrossRef] 
157. Zalite, K.; Voormansik, K.; Praks, J.; Antropov, O.; Noorma, M. Towards detecting mowing of agricultural grasslands from multi-temporal COSMO-SkyMed data. In Proceedings of the 2014 IEEE Geoscience and Remote Sensing Symposium, Quebec City, QC, Canada, 13-18 July 2014; pp. 5076-5079.

158. Zalite, K.; Antropov, O.; Praks, J.; Voormansik, K.; Noorma, M. Monitoring of agricultural grasslands with time series of X-band repeat-pass interferometric SAR. IEEE J. Sel. Top. Appl. Earth Obs. Remote Sens. 2015, 9, 3687-3697. [CrossRef]

159. Sankey, T.T.; Sankey, J.B.; Weber, K.T.; Montagne, C. Geospatial Assessment of Grazing Regime Shifts and Sociopolitical Changes in a Mongolian Rangeland. Rangel. Ecol. Manag. 2009, 62, 522-530. [CrossRef]

160. Courault, D.; Hadria, R.; Ruget, F.; Olioso, A.; Duchemin, B.; Hagolle, O.; Dedieu, G. Combined use of FORMOSAT-2 images with a crop model for biomass and water monitoring of permanent grassland in Mediterranean region. Hydrol. Earth Syst. Sci. Discuss. 2010, 14, 1731-1744. [CrossRef]

161. Estel, S.; Mader, S.; Levers, C.; Verburg, P.H.; Baumann, M.; Kuemmerle, T. Combining satellite data and agricultural statistics to map grassland management intensity in Europe. Environ. Res. Lett. 2018, 13, 074020. [CrossRef]

162. Griffiths, P.; Nendel, C.; Pickert, J.; Hostert, P. Towards national-scale characterization of grassland use intensity from integrated Sentinel-2 and Landsat time series. Remote Sens. Environ. 2020, 238, 111124. [CrossRef]

163. Kolecka, N.; Ginzler, C.; Pazur, R.; Price, B.; Verburg, P.H. Regional Scale Mapping of Grassland Mowing Frequency with Sentinel-2 Time Series. Remote Sens. 2018, 10, 1221. [CrossRef]

164. Dusseux, P.; Vertès, F.; Corpetti, T.; Corgne, S.; Hubert-Moy, L. Agricultural practices in grasslands detected by spatial remote sensing. Environ. Monit. Assess. 2014, 186, 8249-8265. [CrossRef] [PubMed]

165. Price, K.P.; Guo, X.; Stiles, J.M. Optimal Landsat TM band combinations and vegetation indices for discrimination of six grassland types in eastern Kansas. Int. J. Remote Sens. 2002, 23, 5031-5042. [CrossRef]

166. Xu, H.; Wang, X.; Zhang, X. Alpine grasslands response to climatic factors and anthropogenic activities on the Tibetan Plateau from 2000 to 2012. Ecol. Eng. 2016, 92, 251-259. [CrossRef]

167. Xu, D.; Chen, B.; Yan, R.; Yan, Y.; Sun, X.; Xu, L.; Xin, X. Quantitative monitoring of grazing intensity in the temperate meadow steppe based on remote sensing data. Int. J. Remote Sens. 2019, 40, 2227-2242. [CrossRef]

168. Long, Y.; Li, Z.; Wei, L.; Hua-Kun, Z. Using remote sensing and GIS technologies to estimate grass yield and livestock carrying capacity of alpine grasslands in Golog Prefecture, China. Pedosphere 2010, 20, 342-351.

169. Ma, Q.; Chai, L.; Hou, F.; Chang, S.; Ma, Y.; Tsunekawa, A.; Cheng, Y. Quantifying Grazing Intensity Using Remote Sensing in Alpine Meadows on Qinghai-Tibetan Plateau. Sustainability 2019, 11, 417. [CrossRef]

170. Gomez-Gimenez, M.; de Jong, R.; Peruta, R.D.; Keller, A.; Schaepman, M.E. Determination of grassland use intensity based on multi-temporal remote sensing data and ecological indicators. Remote Sens. Environ. 2017, 198, 126-139. [CrossRef]

171. Paudel, K.P.; Andersen, P. Assessing rangeland degradation using multi temporal satellite images and grazing pressure surface model in Upper Mustang, Trans Himalaya, Nepal. Remote Sens. Environ. 2010, 114, 1845-1855. [CrossRef]

172. Grant, K.; Siegmund, R.; Wagner, M.; Hartmann, S. Satellite-based assessment of grassland yields. Int. Arch. Photogramm. Remote Sens. Spat. Inf. Sci. 2015, 40, 15. [CrossRef]

173. Stumpf, F.; Schneider, M.K.; Keller, A.; Mayr, A.; Rentschler, T.; Meuli, R.G.; Schaepman, M.; Liebisch, F. Spatial monitoring of grassland management using multi-temporal satellite imagery. Ecol. Indic. 2020, 113, 106201. [CrossRef]

174. Blair, J.; Nippert, J.; Briggs, J. Grassland ecology. In Ecology and the Environment; Springer: New York, NY, USA, 2014; pp. 389-423.

175. Sinha, S.; Jeganathan, C.; Sharma, L.; Nathawat, M. A review of radar remote sensing for biomass estimation. Int. J. Environ. Sci. Technol. 2015, 12, 1779-1792. [CrossRef]

176. Wiseman, G.; McNairn, H.; Homayouni, S.; Shang, J. RADARSAT-2 polarimetric SAR response to crop biomass for agricultural production monitoring. IEEE J. Sel. Top. Appl. Earth Obs. Remote Sens. 2014, 7, 4461-4471. [CrossRef]

177. Berger, K.; Atzberger, C.; Danner, M.; D’Urso, G.; Mauser, W.; Vuolo, F.; Hank, T. Evaluation of the PROSAIL model capabilities for future hyperspectral model environments: A review study. Remote Sens. 2018, 10, 85. [CrossRef] 
178. Psomas, A.; Kneubühler, M.; Huber, S.; Itten, K.; Zimmermann, N. Hyperspectral remote sensing for estimating aboveground biomass and for exploring species richness patterns of grassland habitats. Int. J. Remote Sens. 2011, 32, 9007-9031. [CrossRef]

179. Pacheco-Labrador, J.; El-Madany, T.S.; Martin, M.P.; Gonzalez-Cascon, R.; Carrara, A.; Moreno, G.; Perez-Priego, O.; Hammer, T.; Moossen, H.; Henkel, K.; et al. Combining hyperspectral remote sensing and eddy covariance data streams for estimation of vegetation functional traits. Biogeosci. Discuss. 2020. preprint. [CrossRef]

180. Atzberger, C.; Darvishzadeh, R.; Schlerf, M.; Le Maire, G. Suitability and adaptation of PROSAIL radiative transfer model for hyperspectral grassland studies. Remote Sens. Lett. 2013, 4, 55-64. [CrossRef]

181. Atzberger, C.; Darvishzadeh, R.; Immitzer, M.; Schlerf, M.; Skidmore, A.; Le Maire, G. Comparative analysis of different retrieval methods for mapping grassland leaf area index using airborne imaging spectroscopy. Int. J. Appl. Earth Obs. Geoinf. 2015, 43, 19-31. [CrossRef]

182. Darvishzadeh, R.; Atzberger, C.; Skidmore, A.; Schlerf, M. Mapping grassland leaf area index with airborne hyperspectral imagery: A comparison study of statistical approaches and inversion of radiative transfer models. ISPRS J. Photogramm. Remote Sens. 2011, 66, 894-906. [CrossRef]

183. Running, S.W.; Nemani, R.R.; Heinsch, F.A.; Zhao, M.; Reeves, M.; Hashimoto, H. A continuous satellite-derived measure of global terrestrial primary production. Bioscience 2004, 54, 547-560. [CrossRef]

184. Gaffney, R.; Porensky, L.M.; Gao, F.; Irisarri, J.G.; Durante, M.; Derner, J.D.; Augustine, D.J. Using APAR to Predict Aboveground Plant Productivity in Semi-Arid Rangelands: Spatial and Temporal Relationships Differ. Remote Sens. 2018, 10, 1474. [CrossRef]

185. Niu, B.; He, Y.; Zhang, X.; Fu, G.; Shi, P.; Du, M.; Zhang, Y.; Zong, N. Tower-Based Validation and Improvement of MODIS Gross Primary Production in an Alpine Swamp Meadow on the Tibetan Plateau. Remote Sens. 2016, 8, 592. [CrossRef]

186. Zhu, X.; Pei, Y.; Zheng, Z.; Dong, J.; Zhang, Y.; Wang, J.; Chen, L.; Doughty, R.B.; Zhang, G.; Xiao, X. Underestimates of grassland gross primary production in MODIS standard products. Remote Sens. 2018, 10, 1771. [CrossRef]

187. Zhu, X.; Li, C.; Tang, L. Assessing the spatiotemporal dynamic of NPP in desert steppe and its response to climate change from 2003 to 2017: A case study in Siziwang banner. In Proceedings of the Remote Sensing for Agriculture, Ecosystems, and Hydrology XXI, Strasbourg, France, 21 October 2019; Volume 11149, pp. 449-454.

188. Lei, T.; Wu, J.; Li, X.; Geng, G.; Shao, C.; Zhou, H.; Wang, Q.; Liu, L. A new framework for evaluating the impacts of drought on net primary productivity of grassland. Sci. Total Environ. 2015, 536, 161-172. [CrossRef] [PubMed]

189. Reinermann, S.; Gessner, U.; Asam, S.; Kuenzer, C.; Dech, S. The Effect of Droughts on Vegetation Condition in Germany: An Analysis Based on Two Decades of Satellite Earth Observation Time Series and Crop Yield Statistics. Remote Sens. 2019, 11, 1783. [CrossRef]

190. Demombynes, G.; Kiringai, J. The Drought and Food Crisis in the Horn of Africa: Impacts and Proposed Policy Responses for Kenya; World Bank: Washington, DC, USA, 2011.

191. Vogel, A.; Scherer-Lorenzen, M.; Weigelt, A. Grassland resistance and resilience after drought depends on management intensity and species richness. PLoS ONE 2012, 7, e36992. [CrossRef]

192. Na, Y.; Li, J.; Hoshino, B.; Bao, S.; Qin, F.; Myagmartseren, P. Effects of Different Grazing Systems on Aboveground Biomass and Plant Species Dominance in Typical Chinese and Mongolian Steppes. Sustainability 2018, 10, 4753. [CrossRef]

193. Schmidt, M.; Carter, J.; Stone, G.; O Reagain, P. Integration of Optical and X-Band Radar Data for Pasture Biomass Estimation in an Open Savannah Woodland. Remote Sens. 2016, 8, 989. [CrossRef]

194. Bégué, A.; Arvor, D.; Bellon, B.; Betbeder, J.; De Abelleyra, D.; PD Ferraz, R.; Lebourgeois, V.; Lelong, C.; Simes, M.; R Verón, S. Remote sensing and cropping practices: A review. Remote Sens. 2018, 10, 99. [CrossRef]

195. Ozdogan, M.; Yang, Y.; Allez, G.; Cervantes, C. Remote sensing of irrigated agriculture: Opportunities and challenges. Remote Sens. 2010, 2, 2274-2304. [CrossRef]

196. Kawamura, K.; Akiyama, T.; Yokota, H.; Tsutsumi, M.; Yasuda, T.; Watanabe, O.; Wang, S. Quantifying grazing intensities using geographic information systems and satellite remote sensing in the Xilingol steppe region, Inner Mongolia, China. Agricu. Ecosyst. Environ. 2005, 107, 83-93. [CrossRef]

197. Yang, X.; Guo, X.; Fitzsimmons, M. Assessing light to moderate grazing effects on grassland production using satellite imagery. Int. J. Remote Sens. 2012, 33, 5087-5104. [CrossRef] 
198. Thornton, P.K.; van de Steeg, J.; Notenbaert, A.; Herrero, M. The impacts of climate change on livestock and livestock systems in developing countries: A review of what we know and what we need to know. Agric. Syst. 2009, 101, 113-127. [CrossRef]

199. Reinfelds, I. Monitoring and Assessment of Surface Water Abstractions for Pasture Irrigation from Landsat Imagery: Bega-Bemboka River, NSW, Australia. Water Resour. Manag. 2011, 25, 2319-2334. [CrossRef]

200. Cilia, C.; Panigada, C.; Rossini, M.; Meroni, M.; Busetto, L.; Amaducci, S.; Boschetti, M.; Picchi, V.; Colombo, R. Nitrogen status assessment for variable rate fertilization in maize through hyperspectral imagery. Remote Sens. 2014, 6, 6549-6565. [CrossRef]

201. Xia, T.; Miao, Y.; Wu, D.; Shao, H.; Khosla, R.; Mi, G. Active optical sensing of spring maize for in-season diagnosis of nitrogen status based on nitrogen nutrition index. Remote Sens. 2016, 8, 605. [CrossRef]

(C) 2020 by the authors. Licensee MDPI, Basel, Switzerland. This article is an open access article distributed under the terms and conditions of the Creative Commons Attribution (CC BY) license (http://creativecommons.org/licenses/by/4.0/). 